NBER WORKING PAPER SERIES

\title{
THE HIGHEST PRICE EVER: THE GREAT \\ NYSE SEAT SALE OF 1928-1929 \\ AND CAPACITY CONSTRAINTS
}

\author{
Lance E. Davis \\ Larry Neal \\ Eugene N. White \\ Working Paper 11556 \\ http://www.nber.org/papers/w11556
}

\section{NATIONAL BUREAU OF ECONOMIC RESEARCH \\ 1050 Massachusetts Avenue \\ Cambridge, MA 02138}

August 2005

We thank seminar participants at the Columbia Macro Lunch, the NBER Summer Institute, the New York Stock Exchange and Universidad Carlos III. We owe particular thanks to Marc Weidenmier and Kim Oosterlinck for their extensive comments. We gratefully acknowledge support from the National Science Foundation (34-3262-00-0-79-151) and the Rutgers University Research Council. The views expressed herein are those of the author(s) and do not necessarily reflect the views of the National Bureau of Economic Research.

(C2005 by Lance E. Davis, Larry Neal and Eugene N. White. All rights reserved. Short sections of text, not to exceed two paragraphs, may be quoted without explicit permission provided that full credit, including () notice, is given to the source. 
Reallocation, Firm Turnover, and Efficiency: Selection on Productivity or Profitability?

Lance E. Davis, Larry Neal and Eugene N. White

NBER Working Paper No. 11556

August 2005

JEL No. N2, G2

\section{$\underline{\text { ABSTRACT }}$}

A surge in orders during the stock market boom of the late 1920s collided against the constraint created by the fixed number of brokers on the New York Stock Exchange. Estimates of the determinants of individual stock bid-ask spreads from panel data reveal that spreads jumped when volume spiked, confirming contemporary observers complaints that there were insufficient counterparties. When the position of the NYSE as the dominant exchange became threatened, the management of the exchange proposed a 25 percent increase in the number of seats in February 1929 by issuing a quarter-seat dividend to all members. While such a "stock split" would be expected to leave the aggregate value of the NYSE unchanged, an event study reveals that its value rose in anticipation of increased efficiency. These expectations were justified as bid-ask spreads became less sensitive to peak volume days after the increase in seats.

Lance E. Davis

Humanities and Social Sciences

California Institute of Technology

1200 East California Boulevard MC 228-77

Pasadena, CA 91125

and NBER

led@hss.caltech.edu

Larry D. Neal

328A David Kinley Hall

1407 W. Gregory Drive

University of Illinois

Urbana, IL 61801

and NBER

lneal@uiuc.edu
Eugene N. White

Department of Economics

Rutgers University

New Brunswick, NJ 08901-1248

and NBER

white@economics.rutgers.edu 
In February 1929, the New York Stock Exchange decided to increase its membership, fixed at 1,100 since 1879, by 25 percent. This expansion occurred when business was booming and the real price of a seat on the exchange was the highest it has ever been. But in this exuberant era, the NYSE was under extraordinary pressure. Members found it increasingly difficult to handle the rising flow of orders. At peak times, there was a scramble on the floor to find counterparties and process trades; and some observers claimed that bid-ask spreads widened. These problems contributed to the slow erosion of the NYSE's share of the national equity market. While the membership had rejected previous recommendations by the NYSE's leadership, this time they listened and voted to accept a quarter-seat dividend to expand capacity and ensure that the exchange maintained its dominant position.

Drawing upon newspaper accounts and archival materials from the NYSE, we chronicle its internal struggle over how to meet the soaring demand for its services. The management's proposed solution to issue a quarter-seat dividend to each member convinced a majority of brokers that was the best way to expand the exchange's capacity. These dividends were then traded to create new seats that raised the total membership from 1,100 to 1,375 . We conduct event studies of the failed effort to expand the exchange in 1925 and the successful one in 1928-1929. When the news of a possible seat dividend reached the membership in late 1928, seat prices rose. We estimate that there was approximately a 20 percent abnormal return, implying that the increased number of seats was anticipated to make the exchange more efficient, thereby augmenting its aggregate value, rather than leaving it constant.

The effects of order surges on NYSE-listed stocks' bid-ask spreads are then examined, using a panel of individual stocks drawn from high and low volume days, both before and after the increase in the number of seats. In 1928, when volume climbed and the exchange was at capacity, the bid-ask spread became very sensitive to the total number of shares traded on the floor and the dispersion of orders at the posts across the floor. After the increase in the number of seats, these effects were muted and customers' costs did not jump. The brokers thus correctly anticipated the increased attractiveness to customers of the exchange from the seat-dividend, although the expansion only partially addressed the growing competition from other equity markets. 


\section{The Value of a Seat}

Seats on an exchange are capital assets whose prices reflect stockbrokers' expected future profits from the special access offered to them by a seat on the exchange. In contrast to many European exchanges, a distinctive feature of the NYSE has been the fixed number of seats and the vesting of the ownership of the exchange with the owners of the seats. The member-owners determine the number of seats; and before the advent of the New Deal legislation governing the securities exchanges, they had complete control over the rules. The value of their seats is affected by the volume of activity on the exchange and the degree of competition among traders on the exchange and between the exchange and the rest of the market. Thus, seat prices are influenced by the volume and level of stock prices, technology, and the rules that govern trading on the exchange. The supply of stock exchange seats has been relatively constant over time. They are traded in an anonymous auction market operated by the Secretary of the NYSE, characterized by relatively small transactions costs. When a new bid or ask price is made, all members are informed; and current bid and ask prices for seats are posted on the floor of the exchange.

Seat prices provide insight into the efficiency of the exchange under different technology, rules, and regulations. Schwert (1977a) examined the efficiency of the market for seats, using end-of-month seat prices for 1926-1972. In similar studies, Jarrell (1984) and Golbe $(1984,1986)$ used end-of-month postwar data to examine the effects of deregulation on the exchanges. More recently, Keim and Madhavan (1997) employed all bids, offers and sale prices of NYSE seats for 1973-1994 to study the determinants of pricing and the ability of seat prices to predict future activity on the exchange; and Keim and Madhavan (2000) used additional annual data to look at the predictive power of seat prices for future stock market returns. 
Figure 1

Price of Seats on the New York Stock Exchange

1883-1971

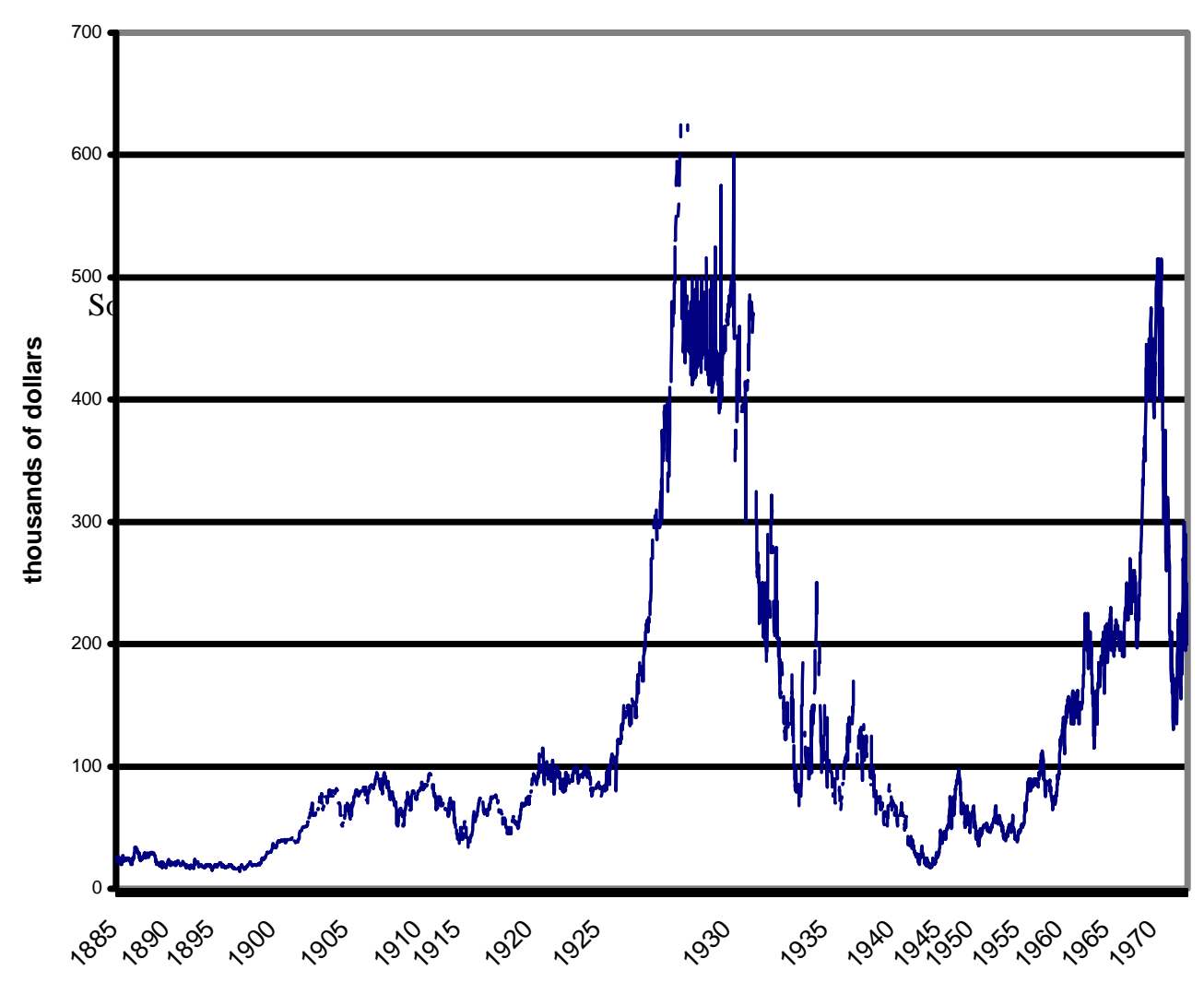

Source: NYSE, Committee on Admissions.

We have collected new data from the archives of the New York Stock exchange for all seat prices from 1879 to 1971. Three volumes of the New York Stock Exchange's Committee on Admissions registered all transfers of membership. The recorded transfers cover the period from November 28, 1879 to January 8, 1880, followed by a gap, and then from December 27, 1883 to June 28, 1971. The exact dates of the transfers are not provided until January 1935. Until that time, all trades during a week were reported as of the end of the week.

Nominal seat prices from 1883 to 1971 are graphed in Figure $1 .{ }^{1}$ The irregular time scale reflects the varying number of trades from year to year and reveals the extraordinary run up in the price of seats and volume of trading that began in 1925. The collapse precedes the 1929 stock market crash, while the low prices afterwards reflect the

\footnotetext{
${ }^{1}$ They are adjusted for the quarter-seat dividend and exclude the prices that were for private sales.
} 
distressed state of the capital markets and the effects of the New Deal regulatory regime. Even by 1971 when our new data set ends, the nominal seat prices had not reached the 1929 high of $\$ 625,000$. The highest price yet attained, $\$ 2,650,000$, was paid on August 23, 1999 at the peak of the most recent boom. In 1929 prices, deflated by the consumer price index, this peak price would have been a mere $\$ 252,000$. If deflated by the Dow Jones Industrials, the 1999 price would have been just $\$ 77,600$. By this measure, the NYSE was at its apogee in the 1920s.

\section{A Flood of Orders and Competition from Rival Exchanges}

In the bull market of the late 1920s, the NYSE's position as the dominant equity market was slowly eroding. Orders were rising because of climbing turnover and new listings. However, the exchange's relatively tough listing standards limited new listing by the "high tech" firms of the day, which were more likely to appear on the New York Curb market and the regional exchanges. Although data on other exchanges are scarce for this period, Table 1 reveals the dimensions of the challenge faced by the NYSE. The New York Curb market was the NYSE's largest competitor but it also complemented the NYSE by taking listings that were below its standards. Chicago was the largest regional exchange. Before the boom, volume on the NYSE was five times greater than on the Curb and dwarfed activity on the Chicago exchange. Between 1927 and 1929, the NYSE's listings rose by over 12 percent, and annual turnover jumped from about 1.0 to 1.5. Yet, many more new issues were listed on the Curb and its volume rose quicker. The Chicago Exchange did not participate in the boom until 1928. It had only 237 stocks listed on January 1, 1927 and 238 a year later. But Chicago reasserted itself; and by January 1, 1929 there were 426 issues, increasing to 519 at the beginning of 1930 . Annual turnover, which had been a mere 0.14 in 1927, rose to 0.62 in 1928 .

New exchanges also opened to accommodate the growing demand for new issues. On June 4, 1928, the Los Angeles exchange created its own Curb to expand capacity to handle new stocks and securities that did not meet the exchange's requirements. The parent exchange saw its total volume increase from 27.1 million in 1027 to 49.4 million in 1928, with the total volume for both Los Angeles exchanges reaching 67.8 million in 
1928. (Commercial and Financial Chronicle Vol. 18, pp. 1647-1649. March 16, 1929). Aggressively pursuing new business, the Los Angeles exchanges played a central role in the opening of the San Diego Stock Exchange in March 1929; their members took half of the forty San Diego seats. (Commercial and Financial Chronicle Vol. 28, March 23, 1929, p. 1827).

Table 1

U.S. Exchange Listings and Volume 1925-1929

\begin{tabular}{|l|r|r|r|r|r|}
\hline & 1925 & 1926 & 1927 & 1928 & 1929 \\
\hline NYSE & & & & & \\
\hline Listed Stocks & 927 & 1043 & 1081 & 1097 & 1177 \\
\hline Number of Shares(millions) & 433 & 492 & 585 & 654 & 757 \\
\hline Market Value (millions) & 27,072 & 34,489 & 38,376 & 49,736 & 67,472 \\
\hline Annual Volume (millions) & 452 & 449 & 576 & 921 & 1124 \\
\hline Annual Turnover & 1.04 & 0.91 & 0.98 & 1.41 & 1.48 \\
\hline & & & & & \\
\hline NEW YORK CURB & & & & & \\
\hline Annual Volume (millions) & 88 & 116 & 125 & 236 & 474 \\
\hline & & & & & \\
\hline CHICAGO & & & & & \\
\hline Listed Stocks & & & 237 & 238 & 426 \\
\hline Number of Shares(millions) & & & 77.2 & 91.5 & 132 \\
\hline Market Value (millions) & & & 5,200 & 6,069 & 9,328 \\
\hline Annual Volume (millions) & 14.1 & 10.2 & 10.7 & 38.9 & 82.2 \\
\hline Annual Turnover & & & 0.14 & 0.43 & 0.62 \\
\hline
\end{tabular}

Source: NYSE Report of the President, (1929), New York Curb Exchange (1929) Chicago Exchange (1930).

These exchanges not only handled new regional business but poached trading from New York. Examining the volume reported in the Bank and Quotation Record for the Baltimore, Boston, Chicago, Cleveland, Detroit, Los Angeles, Philadelphia, Pittsburgh and San Francisco exchanges, Arnold et. al. (1998), found that there was a significant overlap of trading on the U.S. stock exchanges. In January 1929, $8.6 \%$ of the trading volume on the NYSE occurred in securities traded on regional exchanges, while the Curb had $27.7 \%$ of its volume in such securities. However, trading in New York stocks was much more important for the regional exchanges, where regional stocks only accounted for $63.7 \%$ of their trading volume, with NYSE and Curb market-listed 
securities representing the remainder. If the NYSE began to experience difficulties in processing orders, the regional exchanges would have been only be too happy to seize its business.

Figure 2

The Relative Shares of the Aggregate Value of U.S. Stock Exchanges 1927-1929
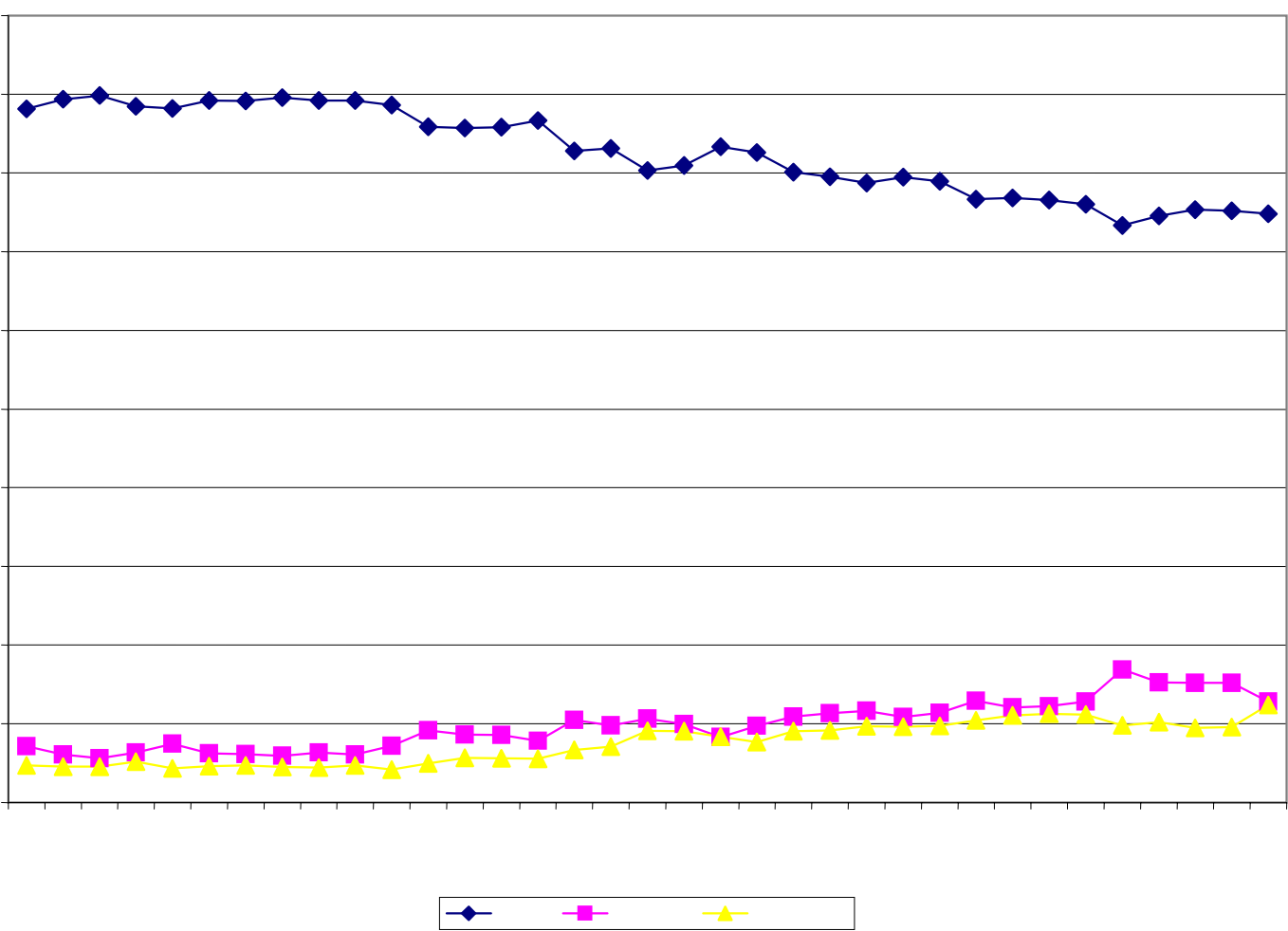

Source: Bond and Quotation Record (1927-1929)

While volume data for many exchanges is sketchy, the problems of the NYSE can be seen in relative aggregate value of American exchanges as measured by the prices of their seats. Given the forward-looking nature of asset prices, the price of seats assesses the future prospects of the exchanges. The bull market led to a general rise in the value of American stock exchanges. The aggregate value of the U.S. exchanges soared from \$220 million in January 1927 to \$372 million a year later, climbing to a peak of \$912 million in September 1929 before collapsing. Although the NYSE increased in value from \$192 to \$687 million from January 1927 to September 1929, it steadily lost “market share” as seen in Figure 2. Averaging 89 percent of all exchanges' value in 1927, the 
NYSE's share of aggregate value dropped to an average of 76 percent in 1929. It is no surprise that many NYSE brokers were alarmed as they watched changing seat prices, which meant that the New York Curb Exchange increased its share from 7 to 13 percent and the regionals from 5 to 10 percent over the same period.

Still, business on the NYSE was certainly good, and the Commercial and Financial Chronicle (October 31, 1925, p. 2109) and the Wall Street Journal (October 29, 1925) gleefully reported new trading records. On October 24, 1924, the NYSE significantly raised its minimum commission per hundred shares, but volume continued to rise. ${ }^{2}$ Yearly sales of shares in 1925 topped the 1919 record and monthly sales the 1901 record. There were more 1 and 2 million share days and consecutive million plus share days than in the previous boom years of 1901 and 1919. This growing flood of monthly orders is shown in Figure 3. At a time when turnover was rising, even the modest increase in new issues placed more stress on the machinery of the NYSE as orders rose rapidly by the middle of the decade. ${ }^{3}$ Higher volume was driven by an increase in the social and geographic span of the market. The rise of the small investor brought about an increase in odd-lot dealings, and the extension of the stock ticker west of the Rocky Mountains added more trading demand. The forthcoming extension of stock ticker services to the Pacific Coast and Florida was anticipated to increase business, and it was feared that unless changes were made, business would be lost to the Curb market and the out-of-town exchanges. (New York Times, November 5, 1925.) Management of the exchange sought to improve its efficiency by acquiring a faster ticker

\footnotetext{
2 Beginning on May 8, 1919, the minimum commission per 100 shares for stocks from $\$ 10$ to $\$ 1247 / 8$ was $\$ 15$ and for shares over $\$ 125$, it was $\$ 20$. After October 30,1924 , the minimum for shares priced from $\$ 10$ to $\$ 997 / 8$ was $\$ 12.50$ plus 0.1 percent of the amount traded rounded down to the nearest $\$ 2.50$. Thus if a share cost $\$ 80$ (The average price of a stock on the NYSE in 1928-1929 was approximately $\$ 80$.), the price of a 100 share trade would be $\$ 20$. Trades from shares ranging from $\$ 100$ to $\$ 1997 / 8$ cost $\$ 25$. (Jones, 2002).

${ }^{3}$ One contributing factor to the rising demand for the services of the NYSE and the Curb was the demise of its onetime great rival, the Consolidated Exchange. Founded in 1885, the Consolidated traded NYSE and Curb listed securities, commodities and petroleum futures, taking business shunned by the NYSE. Unlike the restrictive NYSE, membership was available for "a few hundred dollars, with no questions asked." (Sobel, 1972). It grew rapidly after the panic of 1907; and in 1922, trading records at the Consolidated were broken. At this peak, the Consolidated was wounded by a series of brokerage failures that implicated its president, William S. Silkworth. The scandal was fatal to the Consolidated, which, tarnished by its bucket shop members, lost business to the NYSE. Its closure was announced in 1926, but it did not finally wind down its operations until two years later.
} 
and adding more floor space, but these changes could not alter the constraint that the fixed number of brokers imposed on the supply of counterparties.

Figure 3

Monthly NYSE Stock Sales

1920-1930

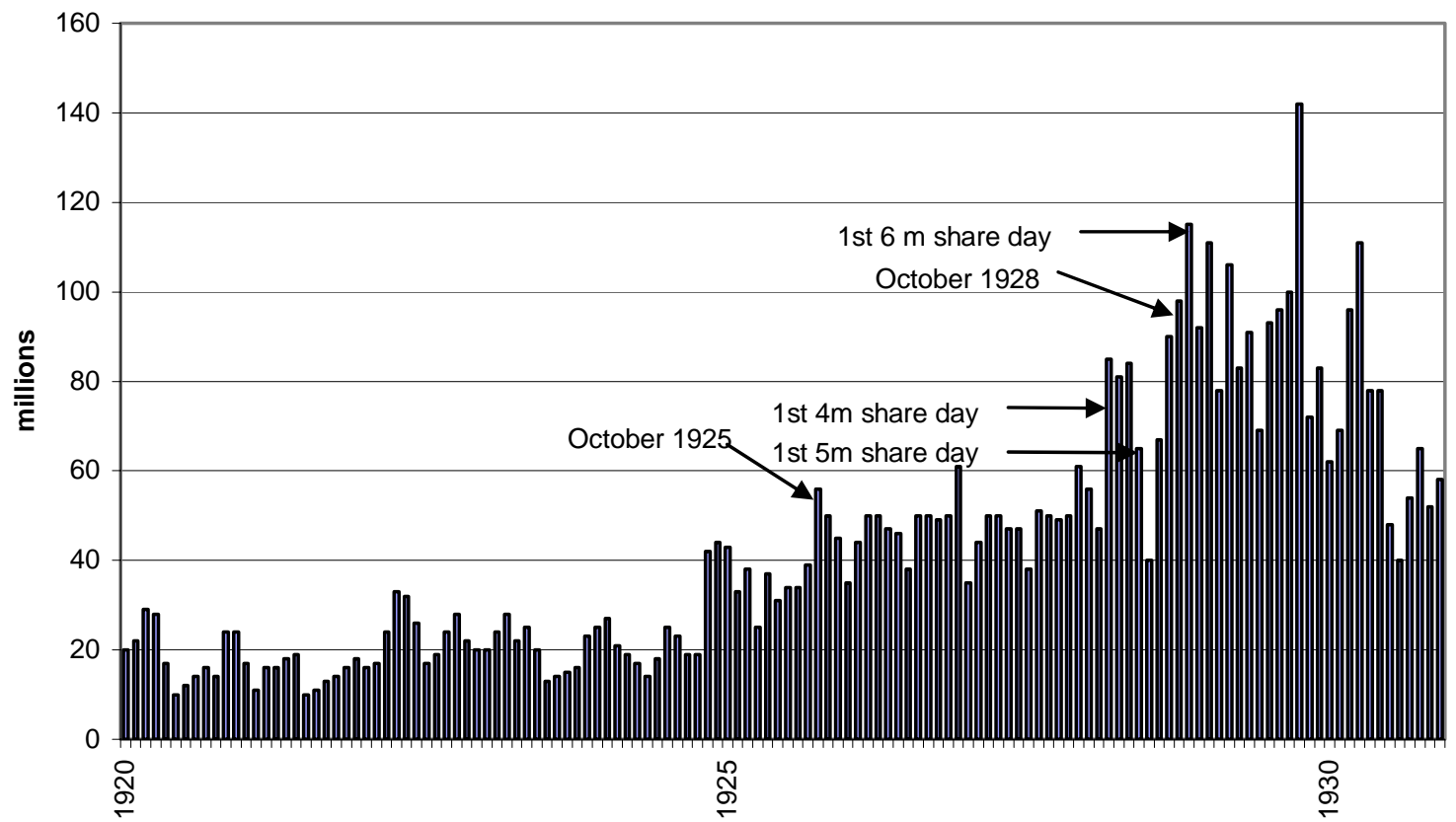

The rising volume of activity strained the Exchange, and a new late closing record of 42 1/2 minutes in 1925 beat the old one of 25 minutes set in 1915. The President of the Stock Clearing Corporation, Samuel F. Streit reported that records were reached in the number and value of stocks cleared:

Settlements of these transactions have congested the machinery of the Stock Exchange and all hands have been called upon to work overtime in clearing the slates each day. All brokers and member firms have been called upon to make their deliveries as early as possible, for the purpose of speeding up the machinery, and banking institutions also have been requested to assist the Stock Clearing Corporation in every possible way. (Commercial and Financial Chronicle, October 31, 1925, p. 2110)

By the mid-twenties, the increased volume of orders regularly delayed settlement, forcing late hours and even a closing of exchange on Saturday; and there was discussion of permitting the delivery of stock two days after the execution of orders instead of on the succeeding day. 
As more orders flooded into the market, trades were handled less efficiently. Volume continued to climb in the second half of the 1920s, problems became more severe, and there were public complaints about the declining performance of the exchange. The NYSE conceded that there were difficulties because of "poor executions and the limited capacity of our market" (Memorandum on Increasing Stock Exchange Memberships, n.d.). The NYSE did not consider a further increase in the minimum commission after 1924, as that would have driven further business to other exchanges.

\section{How Many Brokers?}

On October 28, 1925, the Governing Committee of the NYSE took up the question of how to accommodate the increased demand for services on the exchange. The chairman of the committee, W.B. Nash made the case for more seats (W.B. Nash, Remarks made before the Governing Committee Meeting, October 28, 1925). First, he pointed to the rise in listings and volume. On January 2, 1918, there had been 1,100 bond issues and 625 stock issues listed on the exchange; as of October 1, 1925, there were 1,360 bond and 1,003 stock issues listed. Similarly, the volume of stock sales had doubled from $\$ 1.4$ billion for 1921 to $\$ 2.6$ billion for the first 10 months of 1925 . As membership had not increased since 1879, "a point might soon be reached when there would not be enough active members on the floor to handle adequately the constantly rising volume of orders." Nash argued that capacity required not only "additional space and mechanical facilities but also more members to handle the market.”

The greatest constraint on the efficiency of the exchange was that during surges in volume it was more difficult to find counterparties. The capacity of the exchange was limited by the simple fact that the number of brokers had been fixed nearly fifty years before. After the May 1869 merger of the NYSE, which had 533 members, with the 354 member Open Board of Brokers and the 173 member Government Bond Department, the number of seats was set at 1,060. The only increase incurred in 1879 when the Governing Committee proposed the sale of 40 new memberships, increasing the total seats to 1,100 , to finance the purchase of additional property adjacent to the exchange to ease its physical constraint. The seats were sold to the highest bidders with a minimum 
price of $\$ 10,000$. Although forty more seats would seem unlikely to have had much effect on seat prices, the vote by the membership on the proposal was extremely close, 530 in favor and 510 against. $^{4}$

The fixed number of brokers served the exchange in several capacities. An incoming order for the purchase or sale of a specific stock arrived in the hands of a commission broker who would take the order to the post on the floor of the exchange assigned that specific stock. If it were for less than 100 shares, it would be directly routed to an odd-lot broker who acted as intermediary trader on his own account to accumulate shares into round lots. If there were more incoming orders than he could handle, the commission broker might have some orders handled by a two-dollar brokers for a fee. At the post, the commission broker could trade with another commission broker, a specialist (trading on his own account or as an agent for another broker) who had an affirmative obligation to maintain a continuous market, providing bid and ask prices, or a floor trader trading on his own account. When volume surged, the two-dollar brokers' assistance to harried commission brokers was important to deliver orders to the posts; and, critically for the smooth operation of the market, floor traders helped to maintain a continuous market at the posts, ensuring that "momentary inequalities in the market arising from the mechanical methods of executing the round-share orders of commission houses and odd-lot dealers are instantly smoothed out and eliminated." (Meeker, 1922, p, 101) Thus, floor traders played a key role as counterparties.

Rising volume strained the NYSE's ability to execute trades efficiently in several ways. The number of seats occupied by specialists changed slowly and stood at approximately 150 (Meeker, 1922), but there is no record of how seats were distributed among the different types of brokers. Commission houses in New York and outside of the city opened more branches to handle the inflow of orders; both more than doubled the number of branch offices during the 1920s. Purchases of seats by the out-of-town firms reduced the number of active members on the floor of the exchange. In addition, there were “inactive” seats were held by prominent financiers, including John D. Rockefeller, J. Pierpont Morgan, Frank Jay Gould, Percy A. Rockefeller and Mortimer Schiff, who

\footnotetext{
${ }^{4}$ The memberships were then sold at prices ranging from $\$ 13,500$ to $\$ 15,000$. (W.B. Nash, Remarks made before the Governing Committee Meeting, October 28, 1925)
} 
occasionally appeared to trade on their own account. The total potential number of active New York City brokers on the floor of the exchange on a given day was estimated to be approximately 970 city members less 150 inactive seats. Contemporary observers believed that the ability of the exchange to ensure a continuous market was compromised by the shrinkage in the number of floor traders. Meeker (1922) blamed this loss on the New York State stock transfer stamp tax of 1905 and the federal stamp tax, introduced during World War I. Both the state and federal tax imposed a \$2.00 tax on every sale of 100 shares of stock of $\$ 100$ par value (Goldman, 1914). For a trade, which earned 1/8, or $\$ 12.50$ on 100 shares at $\$ 100$, a floor trader would only earn $\$ 7.50$, after paying $\$ 1.00$ to a commission house to clear the trade and $\$ 4.00$ in taxes. At the beginning of the twenties, Meeker contended that the number of floor traders had fallen from 200 to 50, commenting that "the whole of the market has to a considerable extent been rendered less stable than formerly.” (Meeker, 1922, p. 105). In 1928, the NYSE president made a similar claim that the wartime federal transfer tax had caused the number of floor traders to fall from 200 to 30, and that this small number was a cause of the "wide span between bids and offers on the floor." 5

\section{The Capacity and Bid-Ask Spreads}

How serious the rising trend volume, coupled with peak surges, affected the efficiency of the exchange can be measured by the behavior of the bid-ask spreads. In this period, the New York Times reported daily closing bid-ask spreads for the NYSE stocks in addition to daily volume, high and low prices for the year, high and low prices for the day, opening and closing prices and the change in price from the previous day. Order-flow congestion should have been most severe on peak days. To capture the effects of congestion before and after the quarter-seat dividend, bid-ask spreads and other data need to be compared to low volume days. To this end, we collected daily data on all stocks from the New York Times for selected days.

\footnotetext{
${ }^{5}$ E.H.H. Simmons, Report of the President NYSE May 1, 1928/May 1, 1929, p. 62 and "Memorandum on Increasing Stock Exchange Memberships,” undated, NYSE Archives.
} 
First, every day from January to October 1928, when the seat increase was proposed, was sorted by volume. The peak five days---June 12, May 16, September 21, September 7, and March 27---were selected. To examine how efficiently the exchange handled peak volume after seats were added, every day from March 1929 to August 1929 was sorted by volume. ${ }^{6} \quad$ The top two volume days, March 26 and March 1, were selected. However, they may not provide a good indication of whether the seat increase eased congestion because few additional seats were effectively added by March and volume was significantly higher at 8.2 million and 6.0 million shares compared with the volume of 5.3 million share on June 12, 1928, the highest pre-dividend volume day, raising the possibility of congestion at a higher volume. To more accurately assess the effect of seat expansion on congestion 1928, three days were picked---August 9, May 22, and August 16, 1929---which nearly matched the peak volume for the period JanuaryOctober 1928. To complete the picture for the period after the addition of new seats, the five lowest volume days’ data for March-August 1929 were collected. The low volumes for January-October 1928 were lower by more than one-half, so only the three lowest were picked and two low days that matched the period after seat expansion were chosen.

The key statistics for all twenty days are presented in Table 3. Relative to low volume days, high volume days, measured either by total daily volume or daily turnover, involved a larger number of stocks, although on a given day several hundred listed stocks were not traded. Higher volume for a particular stock should have brought more counterparties to a post and thereby lowered the spread; but there is no obvious evidence for this effect in the median or modal spread, where one-eighth was the minimum tick. Nor do volumes five times higher seem to lower the mean spread (weighted by sales) or the weighted mean spread as a percentage of the closing price. However, the spreads do seem to be influenced by the distribution of trading. The more concentrated trading was, as measured by the share of sales in the most active stock, the most active 20 stocks or a Herfindahl index of sales, the lower the spreads. Concentrating brokers at fewer posts, which increased the number of potential counterparties at one location, appears to have reduced bid-ask spreads, no matter whether it was a low or high total volume day.

\footnotetext{
${ }^{6}$ The months of November 1928 to February 1929 were omitted as they followed the announcement and no increase in seats had occurred, and selection was halted before the crash of 1929 began.
} 
Table 3

The Cost and Characteristics of Trades on the NYSE

1928-1929

\begin{tabular}{|c|c|c|c|c|c|c|c|c|c|c|c|}
\hline & $\begin{array}{l}\text { No. of } \\
\text { Stocks } \\
\text { Listed }\end{array}$ & $\begin{array}{l}\text { Daily } \\
\text { Volume }\end{array}$ & $\begin{array}{l}\text { Daily } \\
\text { Turnover } \\
\text { (Percent) }\end{array}$ & $\begin{array}{l}\text { No. of } \\
\text { Traded } \\
\text { Stocks }\end{array}$ & $\begin{array}{c}\text { Median } \\
\text { Spread } \\
(\$)\end{array}$ & $\begin{array}{c}\text { Modal } \\
\text { Spread } \\
(\$)\end{array}$ & $\begin{array}{l}\text { Mean } \\
\text { Spread } \\
(\$)\end{array}$ & $\begin{array}{l}\text { Mean } \\
\text { Percent } \\
\text { Spread } \\
\text { (Percent) }\end{array}$ & $\begin{array}{l}\text { Herfindahl } \\
\text { Index for } \\
\text { Trading }\end{array}$ & $\begin{array}{l}\text { Share } \\
\text { of Top } \\
20 \\
\text { stocks }\end{array}$ & $\begin{array}{l}\text { Share } \\
\text { of } \\
\text { Top } \\
\text { Stock }\end{array}$ \\
\hline \multicolumn{12}{|l|}{ Pre-Increase } \\
\hline \multicolumn{12}{|l|}{ High Volume } \\
\hline $6 / 12 / 1928$ & 1,113 & $5,252,425$ & 0.768 & 803 & 1.000 & 1.000 & 0.753 & 1.686 & 112.9 & 34.6 & 7.07 \\
\hline $5 / 16 / 1928$ & 1,098 & $4,965,000$ & 0.735 & 790 & 0.630 & 0.500 & 0.515 & 1.104 & 116.7 & 33.7 & 7.21 \\
\hline 9/21/1928 & 1,122 & $4,861,350$ & 0.689 & 698 & 0.500 & 0.500 & 0.390 & 0.758 & 188.5 & 43.8 & 9.42 \\
\hline 9/7/1928 & 1,122 & $4,855,770$ & 0.688 & 680 & 0.500 & 0.500 & 0.435 & 0.783 & 180.0 & 47.0 & 6.22 \\
\hline $3 / 27 / 1928$ & 1,097 & $4,845,240$ & 0.728 & 727 & 0.500 & 0.250 & 0.405 & 0.650 & 313.0 & 56.3 & 12.83 \\
\hline \multicolumn{12}{|l|}{ Pre-Increase } \\
\hline \multicolumn{12}{|l|}{ Low Volume } \\
\hline $3 / 3 / 1928$ & 1,097 & $1,256,100$ & 0.189 & 535 & 0.500 & 0.250 & 0.352 & 0.589 & 991.5 & 58.0 & 30.45 \\
\hline $7 / 19 / 1928$ & 1,118 & $1,214,200$ & 0.176 & 555 & 0.500 & 0.500 & 0.444 & 0.825 & 237.4 & 49.8 & 9.53 \\
\hline $6 / 23 / 1928$ & 1,113 & 719,100 & 0.105 & 526 & 0.500 & 0.500 & 0.579 & 1.079 & 213.8 & 45.8 & 9.87 \\
\hline $7 / 14 / 1928$ & 1,118 & 512,570 & 0.074 & 448 & 0.500 & 0.500 & 0.350 & 1.099 & 198.1 & 47.3 & 8.05 \\
\hline $7 / 21 / 1928$ & 1,118 & 597,440 & 0.087 & 457 & 0.500 & 0.250 & 0.426 & 0.864 & 256.3 & 55.9 & 8.33 \\
\hline \multicolumn{12}{|l|}{ Post-Increase } \\
\hline \multicolumn{12}{|l|}{ High Volume } \\
\hline $3 / 26 / 1929$ & 1,307 & $8,246,740$ & 0.979 & 831 & 1.000 & 0.500 & 0.675 & 1.452 & 173.3 & 45.9 & 6.51 \\
\hline $3 / 1 / 1929$ & 1,307 & $6,021,300$ & 0.715 & 810 & 0.500 & 0.500 & 0.405 & 0.707 & 121.3 & 40.5 & 4.35 \\
\hline $8 / 9 / 1929$ & 1,257 & $5,022,360$ & 0.517 & 799 & 0.750 & 0.500 & 0.501 & 0.780 & 123.7 & 40.1 & 5.47 \\
\hline $8 / 16 / 1929$ & 1,257 & $4,796,030$ & 0.494 & 779 & 0.500 & 0.500 & 0.379 & 0.693 & 125.6 & 41.0 & 5.27 \\
\hline $5 / 22 / 1929$ & 1,220 & $4,844,130$ & 0.540 & 802 & 0.750 & 1.000 & 0.566 & 0.953 & 160.3 & 44.6 & 6.59 \\
\hline \multicolumn{12}{|l|}{ Post-Increase } \\
\hline \multicolumn{12}{|l|}{ Low Volume } \\
\hline $4 / 20 / 1929$ & 1,205 & $1,292,310$ & 0.150 & 589 & 0.500 & 0.500 & 0.354 & 0.639 & 131.3 & 42.6 & 4.16 \\
\hline $6 / 15 / 1929$ & 1,230 & $1,264,420$ & 0.136 & 588 & 0.500 & 0.250 & 0.470 & 0.788 & 208.6 & 41.7 & 11.05 \\
\hline $6 / 8 / 1929$ & 1,230 & $1,201,500$ & 0.129 & 578 & 0.625 & 0.500 & 0.519 & 0.935 & 171.2 & 45.4 & 7.35 \\
\hline $5 / 25 / 1929$ & 1,220 & $1,210,430$ & 0.135 & 645 & 0.500 & 0.500 & 0.532 & 1.003 & 176.4 & 43.5 & 7.98 \\
\hline $5 / 18 / 1929$ & 1,220 & $1,249,640$ & 0.139 & 613 & 0.500 & 0.500 & 0.484 & 0.781 & 115.9 & 40.4 & 3.85 \\
\hline
\end{tabular}

Sources: New York Stock Exchange, Yearbook (1928-1929), New York Times.

To determine whether peak order flows reduced the efficiency of the NYSE by widening specialists’ bid-ask spreads, a model of the bid-ask spread is required. ${ }^{7} \quad$ By providing liquidity and immediacy to brokers, the specialists who had an obligation to

\footnotetext{
${ }^{7}$ For surveys of the literature see Madhavan (2000) and Stoll (2000).
} 
accept orders, were prevented from maintaining their optimally risk-return portfolio and incurred three possible types of costs: order-processing, inventory and asymmetric information costs (Stoll, 1978 and 2000). The first two costs are both affected by the degree of competition for market making, volume, the number of trades, the risks from price volatility, and the share price (Menyak and Paudyal, 1996). Greater liquidity should have reduced spreads, while volatility should have increased it. Although the spread should be proportional to the price of a security, the NYSE's fixed commissions altered this proportionality, with costs being high for low priced stock, inducing investors to trade in high-priced stock to lower transactions costs and creating a negative relationship between price and spread. The spread may also have served as compensation for asymmetric information costs for the losses that specialists would have incurred from trades with well-informed traders that were recouped from less-informed traders, which the dealer could not have distinguished (Easley and O’Hara, 1987). Given the data limitations of the period, other important factors, including the size of trades and capitalization (Laux, 1993), were not recovered. We estimated the bid-ask spread for the ith stock on date $t$, measured as the log of the closing bid-ask spread divided by the closing price or $\operatorname{lnspread}_{\mathrm{it}}$ :

(1) $\operatorname{lnspread}_{i t}=b_{0}+b_{1}$ lnsales $_{i t}+b_{2}$ lnprice $_{i t}+b_{3}$ lnyearvlty $_{i t}+b_{4}$ Indayvlty $_{i t}+b_{5}$ Incallrate $_{i t}$ $+\mathrm{b}_{6}$ Intotalvolume $\mathrm{t}_{\mathrm{t}}+\mathrm{b}_{7} \operatorname{lnherfindahl}_{\mathrm{t}}$

where lnsales $s_{i t}$ is the $\log$ of the sales for stock $i$, and lnprice ${ }_{i t}$ is the closing price. As standard deviation of returns or market betas are not readily recoverable, volatility is measured by lnyearvlty ${ }_{i t}$, the log of the difference between the yearly high and low price of the stock divided by the closing price and the log of the difference between the daily

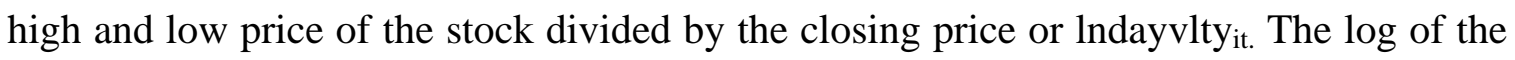
call rate on brokers loans (Board of Governors of the Federal Reserve System, 1943) or lncallrate $_{\text {it }}$ is included as interest costs may have influenced the willingness to hold inventories. The log of total volume, lntotalvolume, ${ }_{t}$ should raise the bid-ask spread if greater activity on the floor increased the difficulty of carrying out trades. If more concentrated trading in stocks lowered the bid ask spread, the variable, lnherfindahl $\mathrm{l}_{\mathrm{t}}$ or 
the log of the Herfindahl index of individual stock sales should have a negative coefficient. We estimated the model using OLS and fixed effects for individual stocks, aimed at capturing some of the individual characteristics of stocks and the omitted variables.

Table 4 reports the coefficients and standard errors for the ordinary least squares estimates for equation 1 and Table 5 shows the fixed effects estimates for the high and low volume days in 1928. Most of the variables for individual listed stocks are tightly estimated. The similarity of the OLS and fixed effects estimates provide some reassurance that omitted characteristics are not driving the results. As expected, higher sales and a higher closing price lowered the bid-ask spread; and, as anticipated more volatility drove the bid-ask spread up. However, even if a stock was traded, there was often no change in the price during the day. In these cases, the difference between the high and low is zero and the daily volatility cannot be calculated. ${ }^{8}$ Nevertheless, dropping those stocks from the regression is a useful check because they were typically less active, smaller issues; and the estimates of the coefficients generally do not change for this smaller sample. Higher daily volatility increases the bid-ask spread; and its introduction mutes the effect of yearly volatility. A higher call loan rate was hypothesized to induce brokers to lower their inventory. For the high volume days, the coefficient confirms this effect, but it is weaker for low volume days. The exchangewide variables, the total volume and the Herfindahl index, are highly correlated (-0.728), making estimation less precise and separate regressions are reported for each variable. This relationship reflects the fact that during the early days of the stock market boom, attention focused on a few favorite stocks. The table reveals that for the high volume days, the higher total volume drove up the bid-ask spread for individual stocks and a higher concentration of trading lowered the spreads, as expected. The coefficients have the same signs during the low volume days; but they have relatively large standard errors, which given the number of observations, cast doubt on their economic significance. Notably, the coefficient on total exchange volume is an order of magnitude lower than on high volume days.

\footnotetext{
${ }^{8}$ For same reason, opening and closing prices and the change from the previous day eliminate many observations. These alternative measures of volatility do not change changes the basic results reported in the tables.
} 
Table 4

OLS Estimates of the Bid-Ask Spreads, 1928

High and Low Volume Days

\begin{tabular}{|c|c|c|c|c|c|c|}
\hline High Volume & & & & & & \\
\hline Sales & -0.247 & -0.247 & -0.315 & -0.316 & -0.247 & -0.315 \\
\hline & 0.007 & 0.007 & 0.009 & 0.009 & 0.007 & 0.009 \\
\hline Closing Price & -0.439 & -0.439 & -0.368 & -0.365 & -0.440 & -0.368 \\
\hline & 0.016 & 0.016 & 0.016 & 0.016 & 0.016 & 0.016 \\
\hline Yearly Volatility & 0.355 & 0.363 & 0.189 & 0.193 & 0.355 & 0.189 \\
\hline & 0.019 & 0.019 & 0.023 & 0.023 & 0.019 & 0.023 \\
\hline Daily Volatility & & & 0.329 & 0.336 & & 0.328 \\
\hline & & & 0.017 & 0.018 & & 0.018 \\
\hline Call Loan Rate & -0.365 & -0.761 & -0.010 & -0.411 & -0.421 & -0.185 \\
\hline & 0.073 & 0.072 & 0.077 & 0.077 & 0.083 & 0.876 \\
\hline Total Exchange Volume & 6.031 & & 4.731 & & 5.397 & 3.632 \\
\hline & 0.405 & & 0.419 & & 0.674 & 0.683 \\
\hline Herfindahl Index & & -0.424 & & -0.350 & -0.076 & -0.114 \\
\hline & & 0.034 & & 0.035 & 0.055 & 0.056 \\
\hline Constant & -89.777 & 6.065 & -69.693 & 5.578 & -77.971 & -52.017 \\
\hline & 6.267 & 0.248 & 6.492 & 0.256 & 10.703 & 10.835 \\
\hline Adjusted R2 & 0.484 & 0.475 & 0.548 & 0.543 & 0.483 & 0.548 \\
\hline Number of Observations & 3641 & 3641 & 2841 & 2841 & 3641 & 2841 \\
\hline Number of Stocks & 976 & 976 & 818 & 818 & 976 & 818 \\
\hline & & & & & & \\
\hline Low Volume & & & & & & \\
\hline Sales & -0.271 & -0.267 & -0.360 & -0.357 & -0.272 & -0.360 \\
\hline & 0.010 & 0.010 & 0.148 & 0.149 & 0.010 & 0.014 \\
\hline Closing Price & -0.455 & -0.456 & -0.363 & -0.363 & -0.454 & -0.363 \\
\hline & 0.018 & 0.019 & 0.025 & 0.024 & 0.019 & 0.025 \\
\hline Yearly Volatility & 0.227 & 0.222 & 0.101 & 0.090 & 0.227 & 0.101 \\
\hline & 0.022 & 0.022 & 0.031 & 0.031 & 0.023 & 0.031 \\
\hline Daily Volatility & & & 0.365 & 0.371 & & 0.364 \\
\hline & & & 0.025 & 0.025 & & 0.024 \\
\hline Call Loan Rate & 0.741 & -0.090 & 0.842 & -0.104 & 0.784 & 0.839 \\
\hline & 0.175 & 0.269 & 0.197 & 0.303 & 0.333 & 0.390 \\
\hline Total Exchange Volume & 0.287 & & 0.288 & & 0.292 & 0.288 \\
\hline & 0.063 & & 0.071 & & 0.066 & 0.076 \\
\hline Herfindahl Index & & -0.061 & & -0.092 & 0.010 & -0.001 \\
\hline & & 0.061 & & 0.069 & 0.063 & 0.072 \\
\hline Constant & -2.401 & 3.311 & -1.970 & 4.126 & -2.568 & -1.956 \\
\hline & 1.102 & 0.816 & 1.239 & 0.924 & 1.553 & 1.843 \\
\hline Adjusted R2 & 0.439 & 0.434 & 0.517 & 0.512 & 0.438 & 0.517 \\
\hline Number of Observations & 2499 & 2499 & 1486 & 1486 & 2499 & 1486 \\
\hline Number of Stocks & 815 & 815 & 565 & 565 & 815 & 565 \\
\hline
\end{tabular}


Table 5

Fixed Effects Estimates of the Bid-Ask Spreads, 1928

High and Low Volume Days

\begin{tabular}{|c|c|c|c|c|c|c|}
\hline High Volume & & & & & & \\
\hline Sales & -0.089 & -0.085 & -0.192 & -0.191 & -0.090 & -0.193 \\
\hline & 0.012 & 0.012 & 0.017 & 0.017 & 0.012 & 0.017 \\
\hline Closing Price & -0.603 & -0.700 & -0.497 & -0.612 & -0.618 & -0.521 \\
\hline & 0.064 & 0.065 & 0.078 & 0.078 & 0.066 & 0.808 \\
\hline Yearly Volatility & 0.253 & 0.301 & 0.173 & 0.218 & 0.251 & 0.172 \\
\hline & 0.040 & 0.040 & 0.046 & 0.046 & 0.040 & 0.046 \\
\hline Daily Volatility & & & 0.283 & 0.294 & & 0.283 \\
\hline & & & 0.022 & 0.022 & & 0.022 \\
\hline Call Loan Rate & -0.191 & -0.553 & 0.010 & -0.280 & -0.244 & -0.054 \\
\hline & 0.083 & 0.079 & 0.093 & 0.089 & 0.091 & 1.000 \\
\hline Total Exchange Volume & 5.135 & & 4.278 & & 4.402 & 3.378 \\
\hline & 0.406 & & 0.451 & & 0.649 & 0.699 \\
\hline Herfindahl Index & & -0.354 & & -0.299 & -0.076 & -0.094 \\
\hline & & 0.033 & & 0.036 & 0.053 & 0.056 \\
\hline Constant & -76.416 & 5.419 & -63.264 & 5.035 & -64.567 & -48.683 \\
\hline & 6.283 & 0.356 & 6.990 & 0.390 & 10.332 & 11.121 \\
\hline Adjusted R2 & 0.388 & 0.361 & 0.504 & 0.479 & 0.398 & 0.502 \\
\hline Number of Observations & 3641 & 3641 & 2841 & 2841 & 3641 & 2841 \\
\hline Number of Stocks & 976 & 976 & 818 & 818 & 976 & 818 \\
\hline & & & & & & \\
\hline Low Volume & & & & & & \\
\hline Sales & -0.078 & -0.070 & -0.180 & -0.170 & -0.077 & -0.179 \\
\hline & 0.015 & 0.015 & 0.024 & 0.024 & 0.015 & 0.024 \\
\hline Closing Price & -0.858 & -0.879 & -0.667 & -0.704 & -0.862 & -0.684 \\
\hline & 0.109 & 0.109 & 0.149 & 0.148 & 0.110 & 0.149 \\
\hline Yearly Volatility & 0.178 & 0.151 & 0.082 & -0.028 & 0.160 & -0.016 \\
\hline & 0.047 & 0.056 & 0.063 & 0.074 & 0.057 & 0.074 \\
\hline Daily Volatility & & & 0.218 & 0.221 & & 0.221 \\
\hline & & & 0.033 & 0.033 & & 0.033 \\
\hline Call Loan Rate & 0.849 & 0.330 & 1.070 & -0.124 & 0.711 & 0.312 \\
\hline & 0.176 & 0.239 & 0.226 & 0.295 & 2.990 & 0.382 \\
\hline Total Exchange Volume & 0.134 & & 0.196 & & 0.125 & 0.135 \\
\hline & 0.057 & & 0.072 & & 0.059 & 0.076 \\
\hline Herfindahl Index & & -0.744 & & -0.252 & -0.038 & -0.203 \\
\hline & & 0.064 & & 0.078 & 0.065 & 0.083 \\
\hline Constant & 0.084 & 3.349 & -1.047 & 5.558 & 0.734 & 2.629 \\
\hline & 1.065 & 0.947 & 1.356 & 1.181 & 1.552 & 2.019 \\
\hline Adjusted R2 & 0.331 & 0.326 & & 0.435 & 0.331 & 0.444 \\
\hline Number of Observations & 2499 & 2499 & 1486 & 1486 & 2499 & 1486 \\
\hline Number of Stocks & 815 & 815 & 565 & 565 & 815 & 565 \\
\hline
\end{tabular}


Table 6

Estimates of the Bid-Ask Spreads, 1928

Combined High and Low Volume Days

\begin{tabular}{|l|r|r|}
\hline & \multicolumn{1}{|l|}{ OLS } & \multicolumn{1}{l|}{$\begin{array}{l}\text { Fixed } \\
\text { Effects }\end{array}$} \\
\hline Sales & -0.272 & -0.113 \\
\hline & 0.010 & 0.012 \\
\hline Closing Price & -0.452 & -0.699 \\
\hline & 0.019 & 0.054 \\
\hline Yearly Volatility & 0.231 & 0.187 \\
\hline & 0.023 & 0.034 \\
\hline Call Loan Rate & 1.079 & 1.045 \\
\hline & 0.329 & 0.297 \\
\hline Total Exchange Volume & 0.346 & 0.200 \\
\hline & 0.065 & 0.059 \\
\hline Herfindahl Index & 0.053 & 0.028 \\
\hline & 0.062 & 0.059 \\
\hline Interaction Sales & 0.026 & 0.042 \\
\hline & 0.012 & 0.012 \\
\hline Interaction Close & 0.012 & 0.012 \\
\hline & 0.024 & 0.022 \\
\hline Interaction Volatility & 0.130 & 0.098 \\
\hline & 0.029 & 0.028 \\
\hline Interaction Call Rate & -1.806 & -1.555 \\
\hline & 0.331 & 0.303 \\
\hline Interaction Herfindahl & -0.439 & -0.337 \\
\hline & 0.067 & 0.061 \\
\hline Interaction Total Volume & 0.295 & 0.229 \\
\hline & 0.058 & 0.052 \\
\hline Constant & -4.087 & -1.667 \\
\hline & 1.532 & 1.433 \\
\hline Adjusted R2 & 0.461 & 0.380 \\
\hline Number of Observations & 6140 & 6140 \\
\hline Number of Stocks & 1020 & 1020 \\
\hline & & \\
\hline & & \\
\hline & & \\
\hline & & \\
\hline & & \\
& &
\end{tabular}


Combining the samples for the high and low volume days, the differences between the two---and the stress on the machinery of the exchange---can be highlighted by checking for any shifts in the coefficients between the two groups in Table 6 . Interaction terms, which indicate how high volume days affected the coefficients, are reported. All of the individual stock variables are generally stable over the high and low volume days. Total exchange volume drives up individual bid-ask spreads, but the effect is pronounced for the high volume days. Also capturing the effect of surges in trading, the Herfindahl index shows little importance on an uncrowded floor, but the interaction term identifies the dispersion of trading as an important variable at capacity. The call loan rate additionally also appears to be stronger on the high volume days. These results confirm that a crowded exchange floor tended to drive up bid-ask spreads. ${ }^{9}$

How much would the bid-ask spread increase by if volume jumped? Table 7 provides estimates of the predicted percentage bid-ask spread, where all variables except total volume have their mean values based on the estimates of Table 5. The first row shows the predicted values when the total exchange volume was set equal to the sample means. ${ }^{10}$ On low volume days, when there was a one percent increase in volume, there was no perceptible effect on the bid-ask spread. An increase from one to two million in total volume increased the bid-ask spread by less than eight one-hundredths of a percent. On the other hand, on peak volume days, higher total exchange volume quickly drove up spreads for individual stocks. With total volume at 4 million, the spread was 0.377 to 0.399 percent. But by the time volume hit 5 million, holding the other variables constant, the spread would have been 0.801 to 0.847 percent. If volume moved to 6 million, the estimates place the spread at 1.483 to 1.568 percent.

\footnotetext{
${ }^{9}$ Additional regressions including the daily volatility produced similar results.

10 These predicted forecasts lie in the range of the bid-ask spread as measured by Jones (2002) for DowJones stocks in the 1920s.
} 
Table 7

Predicted Percentage Bid-Ask Spread

Fixed Effects Estimates

\begin{tabular}{|c|c|c|c|c|}
\hline & $\begin{array}{l}\text { High } \\
\text { Volume }\end{array}$ & $\begin{array}{l}\text { High } \\
\text { Volume }\end{array}$ & $\begin{array}{l}\text { Low } \\
\text { Volume }\end{array}$ & $\begin{array}{l}\text { Low } \\
\text { Volume }\end{array}$ \\
\hline & $\begin{array}{l}\text { Daily } \\
\text { Volatility } \\
\text { Excluded }\end{array}$ & $\begin{array}{l}\text { Daily } \\
\text { Volatility } \\
\text { Included }\end{array}$ & $\begin{array}{l}\text { Daily } \\
\text { Volatility } \\
\text { Excluded }\end{array}$ & $\begin{array}{l}\text { Daily } \\
\text { Volatility } \\
\text { Included }\end{array}$ \\
\hline Mean Total Volume & 0.777 & 0.764 & 0.847 & 0.649 \\
\hline $\begin{array}{l}1 \% \text { Increase } \\
\text { in Total Volume }\end{array}$ & 0.804 & 0.791 & & \\
\hline Total Volume at 4 million & 0.377 & 0.399 & & \\
\hline Total Volume at 5 million & 0.801 & 0.847 & & \\
\hline Total Volume at 6 million & 1.483 & 1.568 & & \\
\hline $\begin{array}{l}\text { 1\% Increase } \\
\text { in Total Volume }\end{array}$ & & & 0.848 & 0.649 \\
\hline Total Volume at 500,000 & & & 0.792 & 0.602 \\
\hline Total Volume at 1 Million & & & 0.864 & 0.661 \\
\hline Total Volume at 2 Million & & & 0.941 & 0.726 \\
\hline
\end{tabular}

The responsiveness of the bid-ask spread reflected the general problems of the exchange in processing and executing orders. The number of brokers on the floor was a hard constraint that translated into higher costs when the floor was swamped with orders. The exchange's leadership saw that higher spreads, slow processing, and rising fails would redirect order flow to other markets. At some point, the position of the NYSE as the most liquid market would begin to decline, undermining its dominance and giving competitors a greater advantage. Although vulnerable to competition from other exchanges and markets, the obvious solution---the addition of more seats---was resisted, as members feared it would dilute the value of the seats they held. 


\section{The Quarter Seat Dividend}

Convinced of the need for more manpower, the Governing Committee presented the members of the Exchange with a proposal on October 28, 1925 to increase the number of seats from 1,100 to 1,125 by the creation of 25 new seats. The committee called for the sale of five seats each at $\$ 135,000, \$ 137,500, \$ 140,000, \$ 142,500$, and $\$ 145,000$. (NYSE Resolution, October 28, 1925; E.H.H. Simmons, Letter to the Members of the NYSE, October 28, 1925; E.H.H. Simmons, Report of the President NYSE May 1, 1925/May 1, 1926, pp. 15-16). The chairman of the Governing Committee, Warren B. Nash, saw a big benefit for all members as the \$3.6 million realized by the sale could be used to pay off part of the Exchange's $\$ 6.5$ million debt on its building, thereby reducing the annual dues of each member by an estimated $\$ 150$.

The optimism of the Governing Committee was not shared by many members, and there was a groundswell of opposition led by Eben Stevens. Opposition members felt that the Governing Committee had acted secretively and against their interests, engineering an increase in competition. (Commercial and Financial Chronicle October 31, 1925, p. 2109 and New York Times, November 5, 1925) In a letter to the president of the exchange, W. Strother Jones, a member of the New York firm of Jones, Maury \& Smith, (Letter to E.H.H. Simmons, W. Strother Jones, October 30, 1925, NYSE archives) voiced his fear that seat prices would soften:

I have...been a member for over 40 years, paid the highest price at which seats had ever sold at that time--\$30,000. They sold not long afterwards at $\$ 17,000$. I have since then bought two seats for my sons, and I made many sacrifices to do so. My immediate family, at $\$ 130,000$, has $\$ 500,000$ in seats. I, before long, will want to sell a seat.

Jones blamed the desire to increase seats on the big firms:

The tendency of large firms is to crowd out the smaller ones in the general commission business. It remains for firms of small capital to do a Floor business or a Clearance business. The big firms have more business than they can properly handle, and instead of giving out business and clearing 
it, hang up and occupy the time of many brokers in straightening out trades.

Here, Jones appears to have been voicing the frustrations of the two-dollar and floor brokers who were squeezed by the larger firms whose efforts to control more of the volume led to problems in execution and settlement.

Simmons attempted to placate the membership by meeting with them on November 4 to explain his position. However, in the end, the Governing Committee failed to persuade the membership, and the resolution was rejected by a vote of 648 to 268 (New York Times November 12, 1925; New York World, February 3, 1929). After this ignominious defeat, the President of the Exchange, E. H. H. Simmons, reported that the increase was voted down not only because of some members' opposition to increasing the number of seats but also because of the feeling among others that the plan was "too limited to prove really helpful.” (E.H.H. Simmons, Report of the President NYSE May 1, 1928/May 1, 1929, p. 62). Few observers believed this statement, and they pointed out that members expected to see their earnings drop if this proposal had been implemented. (New York World, February 3, 1929; New York Herald, January 26, 1929).

Plans to increase the size of the exchange were abandoned. Not until 1928 when the extraordinary stock market boom began were new plans advanced. Annual NYSE volume rose from 1.6 and 1.5 billion shares in 1925 and 1926 to 1.9 billion in 1927, and then soared to 3.2 and 3.9 billion shares in 1928 and 1929. As seen in Figure 2, there were also huge surges in daily volume. The first 4 million share day was reached in 1928; it was followed quickly by a 5 and then a 6 million share day. Members responded by raising commissions. On February 16, 1928, the Commercial and Financial Chronicle reported that "because of pressure on small-lot business, 75 of the larger firms yesterday advanced their minimum commissions to \$5 for each transaction.”

To process greater flows, the NYSE announced on April 13, 1928 the introduction of a new and speedier stock ticker - a ticker capable of running at twice the speed of the current machines. Then in 1929, a newer model was promised that would operate three times as fast as the old one. A new central quotation system, for reporting the bid and asked quotations was inaugurated at six trading posts on October 1, 1928. By February 11, 1929, it provided service to all posts. To ease physical constraints, the New Bond 
Room was opened on May 14, 1928, adding 6,000 more square feet to the trading floor. Searching for more space, the exchange purchased the Commercial Cable and Blair Buildings on December 21, 1928 (NYSE Yearbook 1928-1929). New enclosed trading posts replaced the old style round posts in 1929 to speed up the management of paperwork and enable the clerks to better assist the harried specialists. When volume was high, the clerical work of entering hundreds of orders in their proper sequence had slowed down the pace of trading (New York Herald, January 26, 1929). However, clerks' roles were narrowly defined, and the Governing Committee adopted a rule that precluded the possibility of clerks acting in any capacity as brokers on the floor. (Commercial and Financial Chronicle December 15, 1928, p. 3337). Thus, while these improvements in space and technology helped, brokers still found it hard to manage the rising volume because of their fixed number.

On October 15, 1928, President Simmons called a special meeting of the Governing Committee to consider again the question of whether the membership should be increased. The outcome of the meeting was the establishment of a Special Committee to consider an increase in membership. Its members included Warren Nash, Allen Lindley, Richard Whitney, Walter Johnson, and Edgar Boody. (NYSE Governing Committee Minutes, October 15, 1928, p. 563; (E.H.H. Simmons, Report of the President NYSE May 1, 1928/May 1, 1929, p. 62).

To avoid a repeat of the 1925 failure, Simmons convoked a meeting of the members on October 30, 1928 where he made the case for an increase in membership. (E.H.H. Simmons, Report of the President NYSE May 1, 1928/May 1, 1929, p. 62, and "Memorandum on Increasing Stock Exchange Memberships" undated. NYSE archives). He pointed out how the growth of the market affected every group of brokers on the exchange. For the commission house and two-dollar brokers, the extension of the New York firms' ticker wires, the establishment of branch offices and advertising by radio had greatly augmented the inflow of business. Simmons observed that the odd-lot houses, whose business was also booming with the growth of the small investors, found it hard to obtain sufficient partners or representatives on the exchange. He told the members:

all this increased business must be poured into our floor through an artificially restricted membership, which has obviously reached its capacity this year for handling the volume of business offered. There is no 
use in continuing our other efforts to extend and expand our business unless a comparable expansion occurs in our membership.

The inflow of orders placed specialists under enormous pressure to execute them and handle the paperwork. He bluntly told the members:

There is no denying that in the great markets of this year, the Stock Exchange has been hampered in giving the public perfect brokerage service because of insufficient attendance on the floor. As our markets grow larger and larger in volume, there is no reason for doubting that poor execution of public orders will continually grow worse.

Simmons believed that the NYSE stood to lose the good will of the American public. He argued dramatically that labor-saving devices had been fully exploited and "no new mechanical device can in the future make up for insufficient members' on the floor to handle the business." The inability to provide high quality service would throw business to the New York Curb Market and the out-of-town exchanges, which were beginning to list issues whose sole market had been in New York. Now that the gold standard had been reestablished, he also saw the specter of competition from the London and Berlin markets. He noted that neither of those two exchanges limited their membership and even the Paris exchange was considering adding new brokers (Memorandum on Increasing Stock Memberships).

The press also reported the New York Stock Exchange as having increasing difficulties in meeting the growing volume of trading. The Commercial and Financial Chronicle (November 24, 1928, pp. 2899-2900) commented:

Scenes on the floor of the Stock Exchange and the Curb Market were the wildest in the history of the two institutions. Every available broker was at work and it was a day in which there was not a moment's rest. About the active posts were literally mobs of milling, shoving, excited brokers trying to catch a bid or fill an offer.

On November 23, 1928, after a record volume of 6.9 million shares, the staffs of most brokerage firms worked through the night, with clerical work still unfinished at dawn. In response, the Governing Committee decided to close the Exchange the next day, 
Saturday, to permit clerks to catch up with their work. The New York Curb Market, as well as the exchanges in Philadelphia, Boston, Pittsburgh, Chicago, and Detroit, also closed to catch up. $^{13}$ During the high volume day, the NYSE ticker was at one point 48 minutes behind and ended the day a half an hour behind. These expensive delays occurred even though the Exchange had taken the extraordinary temporary measure the previous day, of omitting the volume of individual stocks to speed up reporting. This action was accepted, in spite of grave misgivings that it would be impossible for traders to judge the market accurately.

More volume was soon anticipated. Faster ticker service was to be installed in subscribers' offices in Florida in January 1929, where there was a large business from winter vacationers. It was reported that "The new ticker is capable of recording a daily turnover of 7,000,000 shares without delay. The present ticker often falls behind on days when the trading does not exceed 4,000,000 shares." (Commercial and Financial Chronicle November 3, 1928, p. 2451). On the heels of the NYSE, the New York Curb market was extending its ticker service. By early 1929, it had reached as far north as Montreal and as far south as Richmond; and extension to St. Louis was planned (Commercial and Financial Chronicle, March 23, 1929, p. 1310).

Faced with even higher future orders, Simmons proposed the issue of a seat “dividend" for each member that would double the number of seats to 2,200. To provide additional revenue for a future enlargement of the exchange, he recommended an increase in the transfer fee on seats from $\$ 4,000$ to $\$ 10,000$. By increasing the number of seats and improving facilities, Simmons claimed that each exchange member would be able "to have his cake and eat it too."

While Simmons lobbied the membership, the Special Committee sent a poll to the members of the exchange. Members were queried about how quickly---within three months, within one year, or more than one year---they would sell their rights if there were a twenty-five, fifty or one hundred percent increase in membership. In addition, the poll asked if members would try to buy up other rights and thereby be able to nominate a

\footnotetext{
13 The New York Curb, with 550 seats, reporting record high prices for seats (\$120,000 on October 4) (Commercial and Financial Chronicle, October 27, 1928, p. 2305). To cope with the higher volume, the Curb adopted an emergency measure on December 10 that permitted specialists to have a clerk on the floor. (Commercial and Financial Chronicle, December 22, 1928, p. 3482).
} 
candidate if there were a twenty-five or fifty percent increase in membership. (Ballot, NYSE archives, undated) Based on 662 answers, the Special Committee concluded that "a larger proportion of new memberships will be absorbed immediately if the membership is increased by twenty-five percent" instead of fifty or one hundred percent It did appear, though, that many members would hold on to their rights and not sell them immediately. The committee concluded that increasing the number of potential seats further than 25 percent would not result in a much larger immediate increase.

The Special Committee produced a report that recommended a 275 member increase to be achieved by the issue of one-quarter seat rights to all current members. Transfers would begin on February 18, 1929 with all bids and offers in multiples of $\$ 500$. (Special Committee Letter to Members of the New York Stock Exchange, February 7, 1929, NYSE archives) In order to encourage the rapid creation of new seats, the committee proposed that members be required to dispose of their rights within three years. The report carefully justified these recommendations. With the prospect of the installation of a new higher speed ticker, the foremost concern was that the exchange be able to offer efficient service to the public. The committee decided on a twenty-five percent increase because it believed that this was the maximum that could be reasonably accommodated with the NYSE's existing physical space and assuming that 70 to 80 percent (following the existing pattern) of the additional seats would be actively used. Even so, they sought reassurance from the Committee of Arrangements that adjustments could be made on the already crowded floor and telephone facilities.

The Special Committee had received other proposals for increasing the number of persons who could make contracts on the floor of the Exchange. However, the committee rejected these ideas because they believed they would involve either a fundamental change in the nature of the Exchange or the method of doing business on the floor. Among the proposals were: (1) that partners or employees of members be permitted to make contracts, substituting for members, (2) that two classes of members be established with only one having the privilege of trading on the floor, and (3) inactive members could lease their trading privileges. The committee believed that there were certain legal difficulties with most of these proposals and that they undermined the 
"individual moral and financial responsibility that exists today since contracts are made only between members of the exchange." Leasing was criticized because it would weaken the disciplinary power of the Exchange since the penalty of suspension or expulsion for a lessee would be less costly than the same penalty on a member. The committee also believed that members would be at a competitive disadvantage vis-à-vis lessees because the latter would have the same privileges for the mere payment of an annual fee. ${ }^{14}$

The report was signed by Simmons (ex-officio), Johnson, Whitney, Lindley and Nash, but one member of the committee, Boody, dissented. He felt that there was simply not enough physical space on the floor of the exchange to accommodate 275 new members. Instead he proposed that only a 10 percent dividend, creating 110 new seats, be issued and that within the next five years when new additional floor space for the exchange became available 165 memberships be issued at the discretion of the committee. (Letter Edgar Boody, to the Governing Committee, January 19, 1929). (Report, Special Committee to the Governing Committee, NYSE archives, undated ).

On January 21, 1929, the President called another meeting of the Governing Committee where the Special Committee submitted its report. After considering the report, the Governing Committee convened again on January 24 and it voted 31 to 1 adopt the recommendations. (NYSE Governing Committee Minutes, January 21, 1929, pp. 619-620 and January 24, 1929, p. 631). The members seemed well disposed to the proposal. A straw vote revealed that members favored the increase by a ratio of three to one. (New York World February 3, 1929). As the New York Herald (January 26, 1929) wrote, the membership was being asked to “vote themselves a 'melon' of $\$ 137,500,000$ (on the assumption that each right would be worth $\$ 125,000$ ).

The leading opponent of the seat dividend proposal was Edward Allen Pierce. A former member of the stock exchange, Pierce was a partner in one of the largest brokerages, a firm with 18 partners, three of whom were members of the exchange. He complained that there were already one hundred inactive members, individuals who held

\footnotetext{
${ }^{14}$ The committee also disparaged the idea of allowing clerks on the floor as they would not increase the number of individuals able to make contracts. However, clerks would be allowed to assist specialists when the new enclosed trading posts were installed.
} 
seats but rarely used them for trading. Pierce claimed that more seats would dilute their value and would not necessarily increase brokers on the floor. Instead, he proposed that out-of-town members be allowed to lease their seats for a fee to individuals approved by the Admissions Committee. As an example, he suggested that an annual fee of $\$ 50,000$ might be set, with $\$ 30,000$ going to the lessor, $\$ 10,000$ to the Exchange and $\$ 10,000$ apportioned among the members to compensate for the increased competition. Pierce belittled the arguments of the special committee. He argued that there was no validity in the claim of the Special Committee that leasing would undermine the "individual moral and financial responsibility.” He pointed out that many seats were held by individuals who had little or no capital, and whose purchase money has been provided by their firms. Thus, responsibility rested with the firm, not with the individuals, and this would also be the case with leasing. Nor did he find the penalty of expulsion or suspension any more severe for a seat owner or lessee. Pierce labeled as ridiculous the idea that it was unfair for a lessee who paid an annual fee to compete with someone who had paid more by buying their seat. By this logic, it was unfair to allow members who paid different prices for their seats to compete with one another. (E. A. Pierce, Letter to E.H.H. Simmons, January 30, 1929, NYSE archives, New York World February 3, 1929)

One prominent out-of-town member, C. Clothier Jones of Philadelphia, announced that he would vote against the proposal. He contended that the efficiency of operations on the floor of the exchange could be adequately improved by the enlarged space, faster tickers, and telephone quotation service, so that the only remaining problem was one of manpower. (Letter to Ashbel Green, Secretary of the NYSE, C. Clothier Jones, November 1, 1928) After attending a meeting of the Out-of-Town Section of the stock exchange firms, Jones reported that they believed that the lack of manpower on the floor could be met simply by (1) allowing clerks to assist specialists, following the example of the Curb Market rules, (2) permitting inactive seats to be leased, and (3) allowing members to designate a substitute partner for time of absence.(Letter to Ashbel Green, Secretary of the NYSE, C. Clothier Jones, December 17, 1928, NYSE archives).While Pierce and Clothier were opposed to any expansion, some members wanted even more seats than the Special Committee had recommended. E.E MacCronet, an out-of-town member from Detroit, opposed the proposal because he felt that a 25 
percent seat dividend was too modest a step and a 50 or 100 percent seat increase was needed to avoid going through the process again in the near future. (E. E. MacCronet, letter, February 4, 1929, NYSE archives)

Yet, in spite of opposition from these quarters, the Governing Committee had the ear of the membership. On February 7, 1929, by a vote of 782 to 133, the members overwhelmingly approved of the Governing Committee’s resolution. (NYSE Governing Committee Minutes, February 13, 1929, p. 643). Anticipating a favorable vote, the Governing Committee appointed a special committee on January 28, 1929, consisting of Nash, Lindley and Whitney and gave it the power to draft any regulations that it deemed necessary to implement the transfer of the seat dividends and the creation of new memberships. In preparation for the inflow of new members, members began wearing identification badges on the floor. (NYSE Yearbook, 1928-1929).

While the sale of seat dividends and the creation of new seats began smoothly, the crash of the stock market in October 1929 slowed down the process. Between February 7, 1929 and October 26, 1931, 1020 seat dividends were converted into 255 new memberships. ${ }^{15}$ The membership was concerned that the remaining 80 unused rights would not be formed into 20 more seats before the expiration date of February 7, 1932. Thus, on September 9, 1931, 524 members presented a petition to the Governing Committee, requesting that the time to exercise the rights be extended an additional year to February 7, 1933. In response to this petition, the special committee offered the Governing Committee a plan to finish the sale speedily by October 26, 1931. The committee took charge of selling to any applicant, approved by the Committee on Admissions, a membership at a price not less than the price of the last fair market sale. The four dividends for the new membership would be selected by lot and the proceeds divided among the right holders. Alternatively, a membership could be transferred irregardless of price, if four right holders petitioned the committee. As an extra goad, any member who did not dispose of his right prior to February 7, 1932 would be fined \$250. (Letter, Special Committee, to the Governing Committee NYSE, October 26, 1931). After considering the report, the Governing Committee moved on November 4,

\footnotetext{
${ }^{15}$ The only other change afterwards occurred in 1953 when the NYSE repurchased and retired 9 seats, leaving 1,366 outstanding.
} 
1931 that the resolutions contained in the reported be adopted and submitted to the membership. In a vote of 638 to 30 on November 24, 1931, the membership approved of the resolutions (NYSE, Governing Committee Minutes).

While some new seats did not become available until long after the stock market crash, the quarter-seat dividend provided a prompt increase in membership at the height of the boom. Fears that all new seats would be absorbed by out-of-town members or otherwise unused proved to be unfounded. Whether the new seats actually eased the capacity constraint was not immediately clear as volume continued to leap upwards.

\section{Did the Dividend Increase the Value of the NYSE?}

The decision to augment the number of seats by 25 percent was an admission that the structure of the exchange needed to be revamped. Like a stock split or a stock dividend, the seat dividend should not have increased the aggregate value of the exchange unless its efficiency was improved. The change in seat prices reveals a substantial contemporaneous gain in the value of the exchange from the increase in the number of seats. If we take the price of a seat before any discussion of a dividend to be at the October 1928 level of about $\$ 450,000$, the aggregate pre-announcement value of the exchange would have been $\$ 495$ million. Taking the post announcement prices, which fluctuated between $\$ 560,000$ and $\$ 600,000$ (omitting the peak of $\$ 625,000$ ) or the postdividend distribution prices that ranged between $\$ 420,000$ and $\$ 500,000$ ), yields aggregate values between $\$ 605$ to $\$ 660$ million and $\$ 578$ to $\$ 688$ million. The jump in value would have been a grand gain of 20 to 25 percent by this back-of-the-envelope calculation. However, the great bull market was in full swing, and prices of seats may also have been rising because of demand driven by ordinary fundamentals. To examine the effects of the increase in the number of seats on the value of the NYSE, looking for abnormal returns to a seat on the NYSE, we conduct two events studies; the first of the abortive increase in 1925 and the second of the successful increase in 1929 (Campbell, Lo and Mackinlay, 1997). 
Figure 4

NYSE Seat Prices June 1925-January 1926

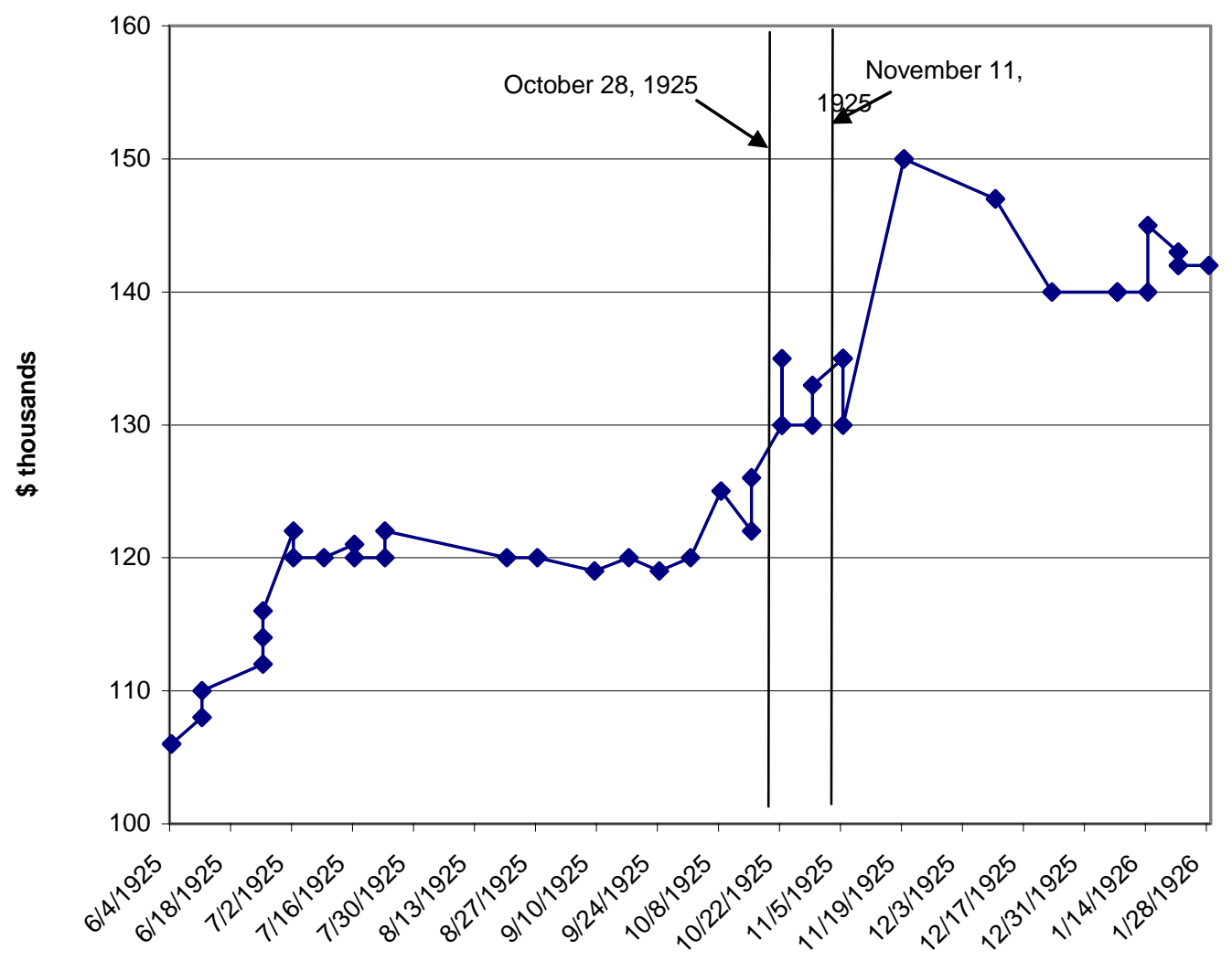

In order to conduct an event study, we need to define the time of the event (Binder, 1998). Prices for seats would move once members became aware of a change in the number of seats and were convinced that it would or would not occur. The movement of seat prices around the 1925 event window is depicted in Figure 4. The first public knowledge of a proposal to increase seats dates was on October 28, 1925 when the Governing Committee issued a resolution to create and sell 25 new seats. This date marks the beginning of the event window, although some discussion of the proposal might have leaked out beforehand. The proposal was rejected by the membership on November 11, 1925, closing the window. This failure seems to have occasioned a rise in seat prices from $\$ 130,000$ to $\$ 150,000$, an increase that may reflect the members' concern that, if it had succeeded, the value of their seats would have been reduced

The event window for the 1928-1929 quarter seat dividend is shown in Figure 5. Members' expectations about the proposed increase in the number of seat probably evolved over time. There was no simple announcement that would have influenced 
prices; and given the failure in 1925, members might well have been skeptical about any new efforts by the leaders of the exchange. The first indication that an increase in the number of seats was possible that we can find in the record, occurred on October 15, 1928 when President Simmons called a special meeting of the Governing Committee to discuss whether to increase membership. Seat prices were already rising before October 15 , although this increase may have been drive by other fundamentals. At the special meeting, the Governing Committee established a Special Committee to investigate the question. However, there might have been some private conversations that leaked out in advance of this meeting; and they could have driven up seat prices. Consequently, selecting this date as the beginning of the event window may underestimate the abnormal return. As he did not want to be accused, as he had in 1925 of being secretive, President Simmons pressed the case for increasing membership in a meeting with members on October 30, 1928. At this point, the potential increase in the number of seats could have ranged from 25 to 100 percent. The official proposal for the quarter-seat dividend came in a report by the Special Committee that was submitted to the Governing Committee on January 21, 1929, before which members had already been informally polled. Three days later on January 24, the Governing Committee reconvened and voted to accept the report's recommendations, a key moment marked on Figure 5. This action was followed by the members' favorable vote on February 7, 1929 that permitted transfers to begin on February 18, 1929. Thus, the second window covers the period from October 15 to February 7 and encompasses a rise in the value of a seat from $\$ 425,000$ to $\$ 600,000$. 
Figure 5

Seat Prices June 1928-February 1929

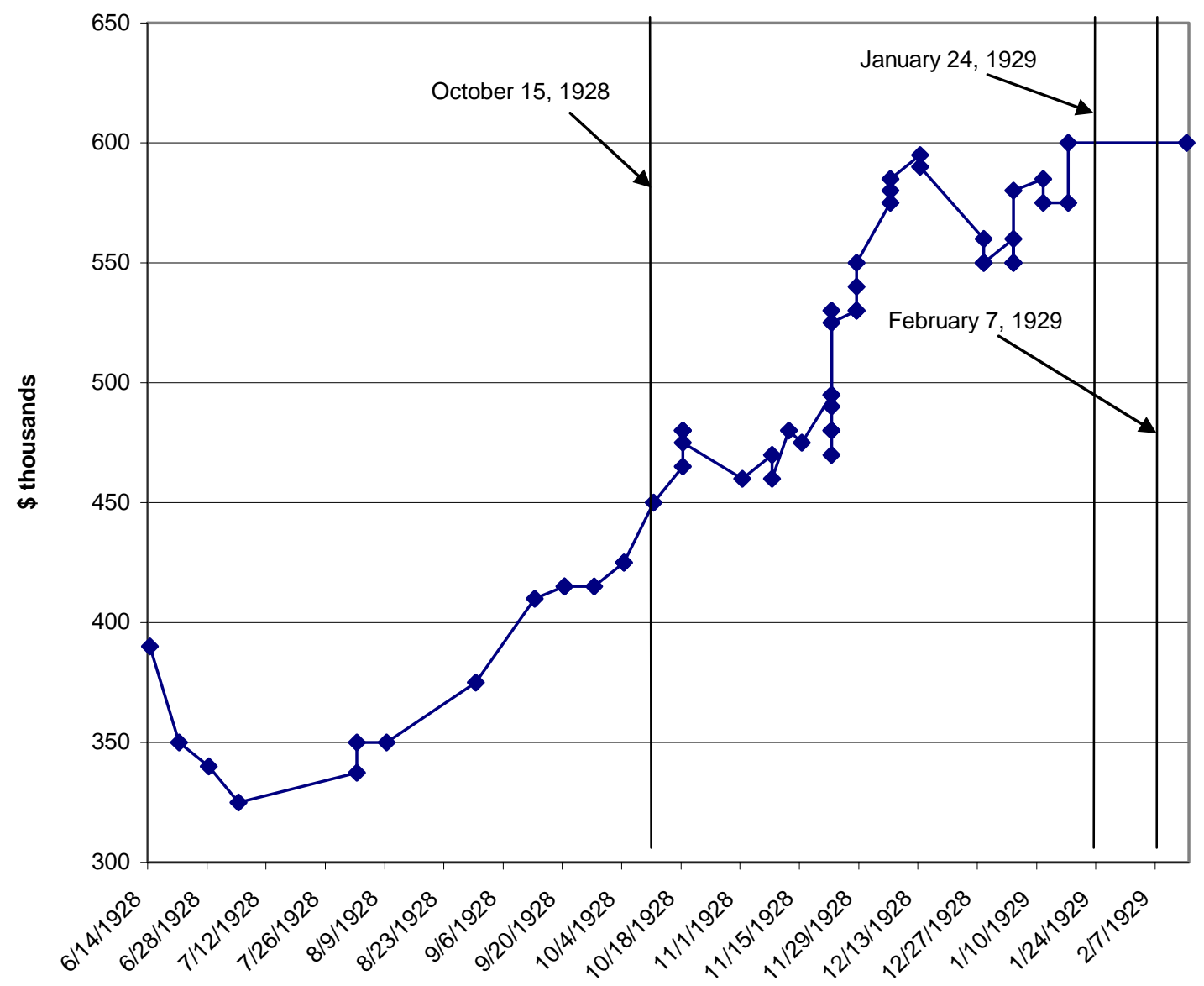

Owing to the fact that the only date for the sale of a seat is the end of the week in which there was a transaction, we restrict our analysis to weekly changes in the prices of seats, taking the last observed sale as the end of week price. The two basic fundamentals that should govern profits for brokers, and hence, seat prices on the exchange are the level of stock prices and the volume of trading. In the simplest model where microstructure, technology and regulation are held constant, profits to brokers should be a function of the level of prices of stocks traded on the NYSE and the volume shares traded. Assuming that the discount rate and commission rate are constant, seat prices will change only if there has been a change in volume or share prices. The two measures of fundamentals we use are the innovations in the Dow Jones Industrials average and the volume of shares traded on the NYSE. As measures, we use both the change in the daily volume from week to week and the change in the volume over the last thirty days. 
Presumably, the first measure gives an indication of the volatility of the volume, while the latter provides information on its trend. These four series were stationary. Using Dickey-Fuller tests we easily rejected the hypothesis that there were unit roots in the time series.

Table 9

Determinants of the Returns to NYSE Seats

\begin{tabular}{|c|c|c|}
\hline & $1920-1925$ & $1920-1928$ \\
\hline Constant & 0.0023 & 0.0045 \\
\hline & 0.0022 & 0.0022 \\
\hline Dow Jones & 0.2479 & 0.2768 \\
\hline & 0.0648 & 0.0637 \\
\hline Daily Volume & -0.0118 & -0.0131 \\
\hline & 0.0049 & 0.0066 \\
\hline 30 Day Volume & 0.0472 & 0.0449 \\
\hline & 0.0131 & 0.0144 \\
\hline Constant & 0.0000 & 0.0000 \\
\hline & 0.0000 & 0.0000 \\
\hline Arch(1) & 0.0385 & 0.0319 \\
\hline Garch(1) & 0.0153 & 0.0153 \\
\hline & 0.948 & 0.9453 \\
\hline Number of Obs. & 0.0201 & 0.0275 \\
\hline Wald Chi-Sq (3) & 214 & 326 \\
\hline Prob>Chi-Sq & 37.4 & 30.9 \\
\hline
\end{tabular}

Note: The terms below the coefficients are the standard errors.

One typical feature of asset return data is that the volatility of asset returns is serially correlated (Campbell, Lo, and MacKinlay, 1997; Poon and Granger, 2003). To capture this feature of the data, a GARCH $(1,1)$ model is employed. The first regression estimates the model, using data from January 8, 1920 to October 22, 1925, the end of the week for the last recorded sale before the opening of the first event window. The results for the determinants of the returns to NYSE seats are presented in Table 9. The estimates for the fundamentals leading up to the first and second events are very similar. A rise in the Dow Jones and the thirty day volume of trades cause a positive change in the return to a NYSE seat. However, if daily volume increases, the return declined. The two 
measures of volume reflect the shifts in day to day volume and movements in the trend. Day-to-day shifts are costly as they represented surprises that may have been difficult to manage and satisfy customers. The Garch model fits the data, which exhibits serial correlation in the returns.

The difference between the observed returns on NYSE seats and the fitted values gives the abnormal returns. Figures 6 and 7 plot the cumulative abnormal returns, beginning several months before the event windows for 1925 and 1929 . In the case of the abortive 1925 attempt to increase the number of seats, there is no movement at the time of the announcement. The members may have doubted that it would succeed, but there is a large sustained leap in the abnormal return immediately after the members voted to block the creation of the new seats, a move that reflected their view that they had preserved the value of their seats.

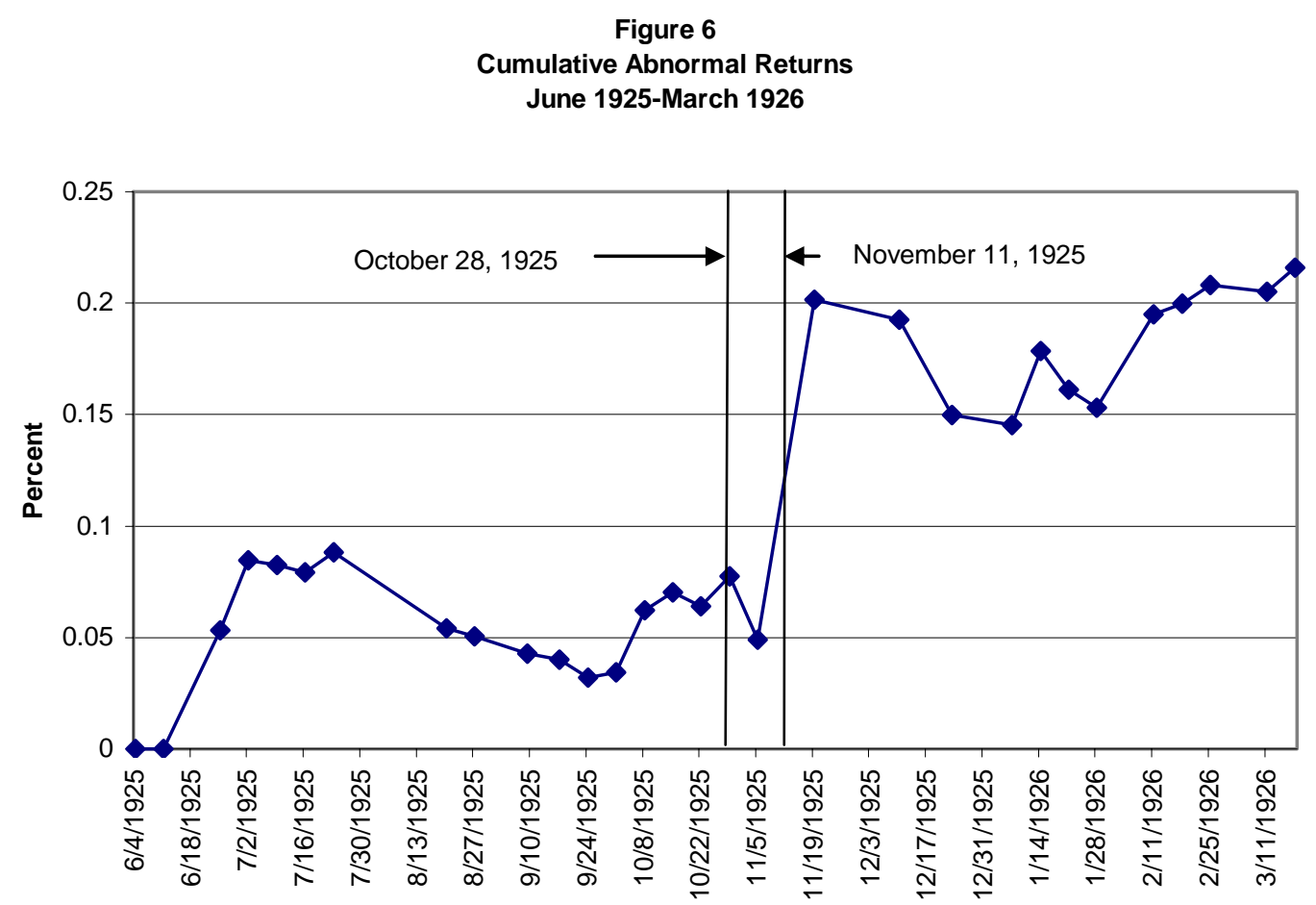

In Figure 7, large cumulative abnormal returns begin at the opening of the event window in 1929 and reach about 20 percent. This increase suggests that about 20 percent of the 35 percent rise in the price of seats may be attributable to the quarter-seat dividend 
with the remainder being driven by the usual fundamentals. The implication is that the potentially greater efficiency of the exchange made the seats more valuable; and they would otherwise have shown no abnormal returns. The brokers expected the expansion to ease the NYSE's capacity constraint and maintain its competitiveness.

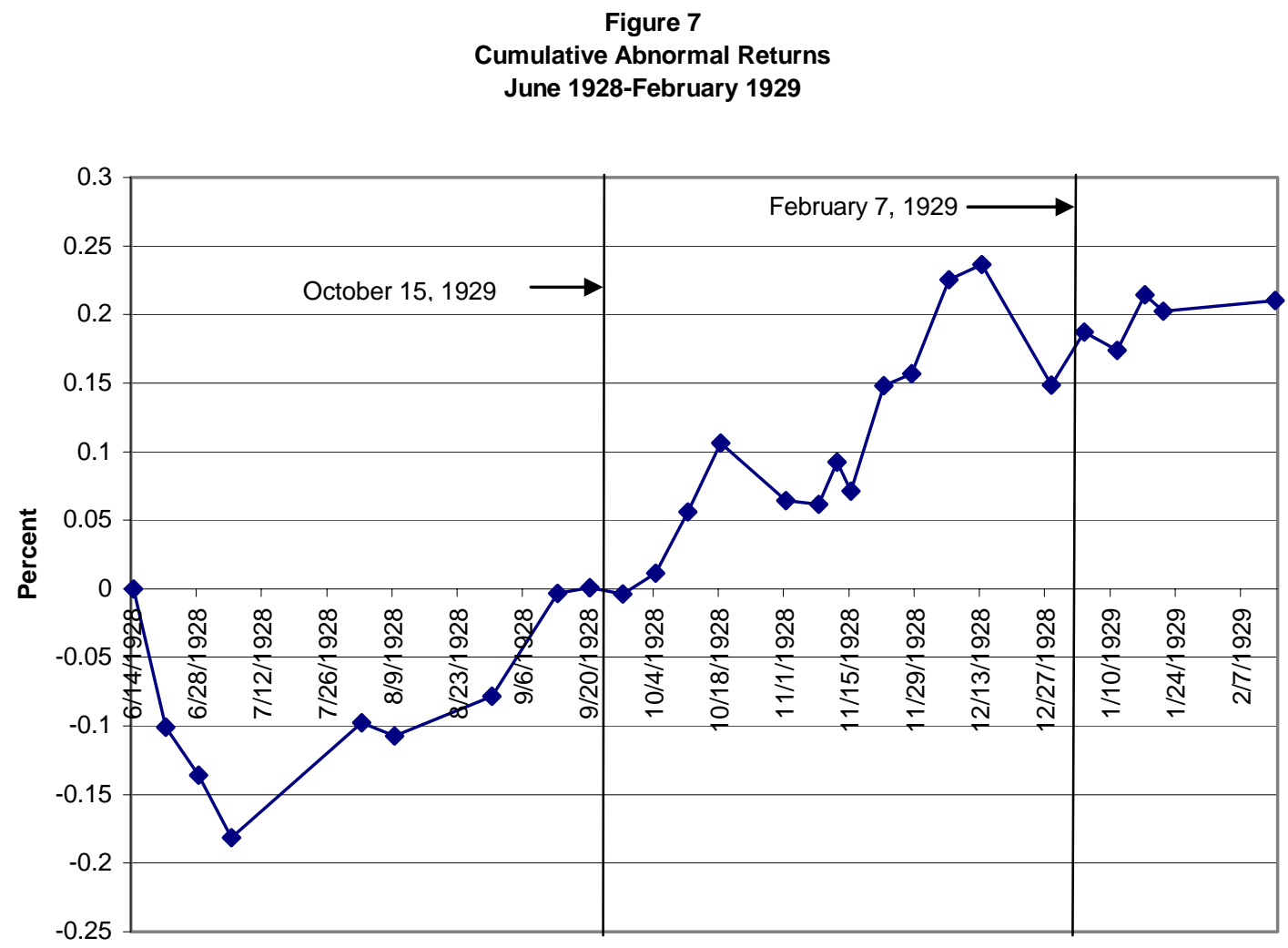

\section{Solution or False Hope?}

The members of the exchange anticipated that they could prevent further erosion of the NYSE's première position by the quarter-seat dividend. However, they may have been too sanguine. As Figure 2 shows, the NYSE's share of the aggregate value of all U.S. exchanges continued to sag through 1929, suggesting that the exchange may have at best slowed the decline. The other exchanges were no laggards; and the West Coast exchanges continued their expansion. Following the NYSE's lead, the Chicago stock exchange declared a 100 percent seat dividend on September 5, 1929 to raise the total seats from 235 to 470 (The Chicago Stock Exchange, 1930). 
Table 9

OLS Estimates of the Bid-Ask Spreads, 1929

High and Low Volume Days

\begin{tabular}{|c|c|c|c|c|c|c|}
\hline High Volume & & & & & & \\
\hline Sales & -0.251 & -0.250 & -0.314 & -0.315 & -0.251 & -0.313 \\
\hline & 0.006 & 0.006 & 0.009 & 0.009 & 0.006 & 0.008 \\
\hline Closing Price & -0.381 & -0.381 & -0.323 & -0.321 & -0.378 & -0.329 \\
\hline & 0.016 & 0.015 & 0.017 & 0.017 & 0.016 & 0.167 \\
\hline Yearly Volatility & 0.337 & 0.328 & 0.196 & 0.206 & 0.336 & 0.194 \\
\hline & 0.018 & 0.016 & 0.022 & 0.020 & 0.018 & 0.021 \\
\hline Daily Volatility & & & 0.257 & 0.247 & & 0.249 \\
\hline & & & 0.017 & 0.016 & & 0.017 \\
\hline Call Loan Rate & -0.231 & 0.939 & -0.016 & 0.978 & 0.866 & 1.064 \\
\hline & 0.111 & 0.162 & 0.117 & 0.170 & 0.172 & 0.181 \\
\hline Total Exchange Volume & 0.245 & & -0.168 & & 0.195 & -0.223 \\
\hline & 0.156 & & 0.163 & & 0.155 & 0.163 \\
\hline Herfindahl Index & & 1.648 & & 1.600 & 1.639 & 1.612 \\
\hline & & 0.197 & & 0.207 & 0.197 & 0.207 \\
\hline Dummy March 26, 1929 & 0.463 & -0.591 & 0.388 & -0.737 & -0.636 & -0.688 \\
\hline & 0.079 & 0.149 & 0.823 & 0.157 & 0.154 & 0.161 \\
\hline Constant & -0.895 & -7.538 & 5.572 & -6.919 & -10.391 & -3.659 \\
\hline & 2.338 & 1.253 & 2.458 & 1.313 & 2.585 & 2.708 \\
\hline Adjusted R2 & 0.463 & 0.471 & 0.503 & 0.512 & 0.471 & 0.512 \\
\hline Number of Observations & 3919 & 3919 & 2989 & 2989 & 3919 & 2989 \\
\hline Number of Stocks & 1094 & 1094 & 910 & 910 & 1094 & 910 \\
\hline Low Volume & & & & & & \\
\hline Sales & -0.294 & -0.295 & -0.382 & -0.384 & -0.294 & -0.382 \\
\hline & 0.008 & 0.008 & 0.013 & 0.013 & 0.008 & 0.013 \\
\hline Closing Price & -0.457 & -0.454 & -0.345 & -0.341 & -0.456 & -0.343 \\
\hline & 0.018 & 0.019 & 0.024 & 0.024 & 0.019 & 0.024 \\
\hline Yearly Volatility & 0.277 & 0.283 & 0.171 & 0.178 & 0.278 & 0.174 \\
\hline & 0.020 & 0.020 & 0.028 & 0.027 & 0.020 & 0.028 \\
\hline Daily Volatility & & & 0.267 & 0.269 & & 0.267 \\
\hline & & & 0.023 & 0.023 & & 0.023 \\
\hline Call Loan Rate & 0.023 & -0.319 & 0.018 & -0.412 & -0.046 & -0.154 \\
\hline & 0.180 & 0.162 & 0.151 & 0.186 & 0.188 & 0.214 \\
\hline Total Exchange Volume & -1.857 & & -1.851 & & -1.805 & -1.734 \\
\hline & 0.626 & & 0.712 & & 0.634 & 0.720 \\
\hline Herfindahl Index & & -0.097 & & -0.168 & -0.514 & -0.129 \\
\hline & & 0.098 & & 0.112 & 0.099 & 0.113 \\
\hline Constant & 28.900 & 3.993 & 29.280 & 4.992 & 28.550 & 28.616 \\
\hline & 8.640 & 0.775 & 0.982 & 0.887 & 8.675 & 9.844 \\
\hline Adjusted R2 & 0.478 & 0.477 & 0.501 & 0.500 & 0.479 & 0.503 \\
\hline Number of Observations & 2981 & 2981 & 1880 & 1880 & 2981 & 1880 \\
\hline Number of Stocks & 923 & 664 & 923 & 664 & 923 & 664 \\
\hline
\end{tabular}


Table 10

Fixed Effects Estimates of the Bid-Ask Spreads, 1929

High and Low Volume Days

\begin{tabular}{|c|c|c|c|c|c|c|}
\hline High Volume & & & & & & \\
\hline Sales & -0.124 & -0.137 & -0.180 & -0.190 & -0.135 & -0.189 \\
\hline & 0.013 & 0.013 & 0.018 & 0.018 & 0.013 & 0.018 \\
\hline Closing Price & -0.549 & -0.462 & -0.428 & -0.335 & -0.474 & -0.344 \\
\hline & 0.066 & 0.065 & 0.072 & 0.071 & 0.066 & 0.071 \\
\hline Yearly Volatility & 0.182 & 0.256 & 0.161 & 0.234 & 0.215 & 0.187 \\
\hline & 0.041 & 0.030 & 0.048 & 0.035 & 0.041 & 0.048 \\
\hline Daily Volatility & & & 0.171 & 0.161 & & 0.163 \\
\hline & & & 0.021 & 0.020 & & 0.021 \\
\hline Call Loan Rate & -0.080 & 0.828 & -0.064 & 0.984 & 0.906 & 1.071 \\
\hline & 0.111 & 0.157 & 0.123 & 0.174 & 0.166 & 0.184 \\
\hline Total Exchange Volume & -0.351 & & -0.343 & & -0.287 & -0.311 \\
\hline & 0.197 & & 0.223 & & 0.195 & 0.219 \\
\hline Herfindahl Index & & 1.528 & & 1.739 & 1.512 & 1.734 \\
\hline & & 0.191 & & 0.212 & 0.191 & 0.212 \\
\hline Dummy March 26, 1929 & 0.566 & & 0.479 & -0.777 & -0.471 & -0.689 \\
\hline & .084 & & 0.094 & 0.159 & 0.155 & 0.170 \\
\hline Constant & 8.285 & -6.953 & 7.927 & -8.533 & -2.448 & -3.700 \\
\hline & 3.069 & 1.286 & 3.466 & 1.423 & 3.325 & 3.697 \\
\hline Adjusted R2 & 0.4775 & 0.506 & 0.577 & 0.590 & 0.509 & 0.600 \\
\hline Number of Observations & 3919 & 3919 & 2989 & 2989 & 3919 & 2989 \\
\hline Number of Stocks & 1094 & 1094 & 910 & 910 & 1094 & 910 \\
\hline Low Volume & & & & & & \\
\hline Sales & -0.112 & -0.116 & -0.175 & -0.1825 & -0.112 & -0.175 \\
\hline & 0.104 & 0.014 & 0.022 & 0.022 & 0.01435 & 0.022 \\
\hline Closing Price & -0.447 & -0.495 & -0.615 & -0.673 & -0.447 & -0.6204 \\
\hline & 0.121 & 0.122 & 0.141 & 0.1409 & 0.122 & 0.1408 \\
\hline Yearly Volatility & 0.2185 & 0.289 & 0.3035 & 0.4779 & 0.219 & 0.376 \\
\hline & 0.218 & 0.063 & 0.0834 & 0.087 & 0.065 & 0.09 \\
\hline Daily Volatility & & & 0.1297 & 0.1401 & & 0.1311 \\
\hline & & & 0.0284 & 0.0284 & & 0.0284 \\
\hline Call Loan Rate & 0.132 & -0.2914 & 0.2439 & -0.502 & 0.127 & -0.0725 \\
\hline & 0.119 & 0.147 & 0.147 & 0.181 & 0.172 & 0.211 \\
\hline Total Exchange Volume & -2.75 & & -3.265 & & -2.746 & -2.8855 \\
\hline & 0.577 & & 0.716 & & 0.593 & 0.738 \\
\hline Herfindahl Index & & -0.108 & & -0.3621 & -0.0036 & -0.2479 \\
\hline & & 0.094 & & 0.1156 & 0.096 & 0.118 \\
\hline Constant & 40.246 & 3.022 & 47.874 & 5.087 & 40.198 & 44.22 \\
\hline & 7.982 & 0.8689 & 9.921 & 1.029 & 8.0855 & 10.06 \\
\hline Adjusted R2 & 0.4137 & 0.3975 & 0.4069 & 0.4204 & 0.4136 & 0.3979 \\
\hline Number of Observations & 2981 & 2981 & 1880 & 1880 & 2981 & 1880 \\
\hline Number of Stocks & 923 & 923 & 664 & 664 & 923 & 664 \\
\hline
\end{tabular}


Whether or not the exchange improved the order flow on the floor and the competitiveness of the exchange should be visible in the behavior of the post-seatdividend bid-ask spreads. Table 9 and 10 report the OLS and Fixed Effects Estimates of equation 1 for the selected days of high and low volume after the increase in seats. A dummy variable for extraordinarily high day of March 26, 1929 when volume climbed above 8 million shares is included to test for any higher level capacity constraint. All the variables for individual stocks strongly resemble the estimates before the seat-dividend, both in sign and significance. However, all the exchange-wide variables are highly correlated, as is the dummy for March 26, 1929, making it difficult to precisely estimate the coefficients. Given this problem, it is hard to judge if there was still a capacity constraint influencing bid-ask spreads. Many variables have contradictory signs and their significance has generally declined. On low volume days, higher total exchange volume may have even reduced spreads.

Combining the high volume days for 1928 and 1929 and low days for 1928 and 1929 reveals the extent of the changes. In regressions, not reported here for the combined pre- and post-dividend low volume days, there are no important changes in either the individual or exchange variables coefficients, as would be expected from the lifting of a constraint that affected peak volume days. Table 11 presents regressions for the combined high volume days before and after the seat-dividend, with the interaction term set to capture the pre-dividend effects. The estimates for the stock specific variables are again stable and similar to previous estimates. The total volume on the exchange has a coefficient more similar to the low volume days; but the interaction term shows that before the dividend was issued higher total volume resulted in higher bid-ask spreads. Similarly, the Herfindahl index is important before the seat increase but not afterwards. Thus, increase in the number of seats appears to have damped down the effect of volume surges on bid-ask spreads. 
Table 11

Estimates of the Bid-Ask Spreads

Combined High Volume Days, 1928 and 1929

\begin{tabular}{|l|r|r|}
\hline & \multicolumn{1}{|l|}{ OLS } & \multicolumn{1}{l|}{$\begin{array}{l}\text { Fixed } \\
\text { Effects }\end{array}$} \\
\hline Sales & -0.254 & -0.188 \\
\hline & 0.006 & 0.007 \\
\hline Closing Price & -0.373 & -0.441 \\
\hline & 0.149 & 0.024 \\
\hline Yearly Volatility & 0.346 & 0.261 \\
\hline & 0.015 & 0.019 \\
\hline Call Loan Rate & 0.860 & 0.863 \\
\hline & 0.171 & 0.161 \\
\hline Total Exchange Volume & 0.226 & -0.080 \\
\hline & 0.151 & 0.149 \\
\hline Herfindahl Index & 1.639 & 1.563 \\
\hline & 0.196 & 0.185 \\
\hline Dummy for 1928 & -56.713 & -56.412 \\
\hline & 9.495 & 9.297 \\
\hline Dummy March 26, 1929 & -0.645 & -0.524 \\
\hline & 0.153 & 0.145 \\
\hline Interaction Sales & 0.008 & 0.060 \\
\hline & 0.008 & 0.009 \\
\hline Interaction Close & -0.072 & -0.117 \\
\hline & 0.021 & 0.023 \\
\hline Interaction Volatility & -0.000 & -0.002 \\
\hline & 0.001 & 0.001 \\
\hline Interaction Call Rate & -1.53 & -1.309 \\
\hline & 0.185 & 0.176 \\
\hline Interaction Herfindahl & -2.043 & -1.932 \\
\hline & 0.199 & 0.188 \\
\hline Interaction Total Volume & 4.546 & 4.451 \\
\hline & 0.612 & 0.599 \\
\hline Constant & -9.292 & -4.473 \\
\hline & 2.507 & 2.465 \\
\hline Adjusted R2 & 0.479 & 0.548 \\
\hline Number of Observations & 6140 & 6140 \\
\hline Number of Stocks & 1020 & 1020 \\
\hline & & \\
\hline
\end{tabular}

The high degree of collinearity among the exchange-wide variables after the seat dividend leads to imprecise estimates of key variables, notably total volume. It is not 
clear whether the increase in the number of seats reduced or eliminated the capacity problem. Many of the coefficients in Tables 9, 10, and 11 suggest that it was no longer a constraint. However, it is worthwhile to look at the estimates where total volume is still indicated as raising spreads, that is, the case of the least improvement. Table 12 presents the predicted spreads for high volume days in 1928 from Table 7 and predictions based on the first column of estimated OLS coefficients in Table 9. For variables other than total volume, the mean values were used. Even in the least improvement case, the response of bid-ask spreads to high volume days was drastically reduced in 1929. A one percent increase in total volume had an imperceptible effect, and the increases from four to five to six million remain modest. The same OLS equation in Table 9 had a positive coefficient on the dummy variable for the 8 million share day on March 26, 1929, suggesting that there was a new higher capacity constraint even with 1,375 seats. At 8 million shares, the bid-ask spread would have jumped to 1.309 percent, but it still would have been far below a predicted 3.92 percent when there were 1,100 seats. Thus, even in the case of least improvement, there was still a substantial weakening of the effects of volume surges on bid-ask spreads.

Table 12

Predicted Percentage Bid-Ask Spread

Fixed Effects Estimates

\begin{tabular}{|l|c|c|}
\hline & $\begin{array}{l}\text { 1928 High } \\
\text { Volume }\end{array}$ & $\begin{array}{l}\text { 1929 High } \\
\text { Volume }\end{array}$ \\
\hline & & \\
\hline Mean Total Volume & 0.777 & 0.759 \\
\hline & & \\
\hline $\begin{array}{l}\mathbf{1} \% \text { Increase } \\
\text { in Total Volume }\end{array}$ & 0.804 & 0.761 \\
\hline Total Volume at 4 million & 0.377 & 0.695 \\
\hline Total Volume at 5 million & 0.801 & 0.734 \\
\hline Total Volume at 6 million & 1.483 & 0.768 \\
\hline Total Volume at 8 million & 3.920 & 1.309 \\
\hline
\end{tabular}




\section{Conclusion}

Normally a split in the rights to an asset does not affect the aggregate value of the asset; but, in the case of the 1920s NYSE, the distribution of a quarter-seat dividend to members raised the value of the exchange. After World War I, the flow of orders was rapidly increasing, and the NYSE reached a capacity constraint that was determined by the fixed number of seats. Given the state of technology and the rules of the exchange, higher order flows produced delays and reduced the quality of service to customers. Concern over the potential loss of business to competing exchanges forced the NYSE to consider its options. Although some members were unhappy, the overwhelming majority found that the creation of a quarter-seat dividend provided them with a means to personally capture the gains from increasing the efficiency of the exchange. The rise in the number of seats eased the pressure on the bid-ask spread from surges in volume. As anticipated, the increase in seats greased the order processing machine on the floor of the exchange and delivered benefits to customers; even as competition from other exchanges continued to grow. The 375 new seats moved, but apparently did not eliminate, the constraint, as critics who pushed for an even greater increase had warned. However, this boundary would not be tested for decades after the Great Depression. Volume had exceeded 5 millions shares on 24 days in 1928 and 36 days in 1929. Afterwards, it was a rare occurrence: one day each in 1937, 1939, 1946, 1959; two days in 1957, 1958 and 1960; and three days in 1955. Only when the go-go years began in 1961 and the exchange experienced volume above 5 million shares on 41 days would the capacity of the exchange be tested again. 


\section{Bibliography}

Arnold, Tom, Philip Hersch, J. Harold Mulerin, and Jeffry Netter, “Merging

Markets,” Journal of Finance Vol. LIV, No. 3, (June 1998), pp. 1083-1107.

Binder, John J., “The Event Study Methodology Since 1969,” Review of Quantitative

Finance and Accounting 11 (1998), 111-137.

Board of Governors of the Federal Reserve, Banking and Monetary Statistics

(Washington, D.C., 1943).

Bond and Quotation Record (Commercial and Financial Chronicle Supplement).

Campbell, John Y. and Andrew W. Lo and A. Craig MacKinlay, The Econometrics of Financial Markets (Princeton: Princeton University Press, 1997).

Chicago Stock Exchange, The Chicago Stock Exchange: A Record of Progess (Chicago:

Chicago Stock Exchange, 1930).

Commercial and Financial Chronicle.

Easley, D. and O’Hara, M, "Price, trade size, and information in securities markets," Journal of Financial Economics 19 (1987), pp. 69-90.

Golbe, Devra L., "Negotiated Commissions, Rule 394 and the Risk and Return to New York Stock Exchange Seat Ownership," Princeton Financial Research Center Memorandum No. 52, (November 1984).

Golbe, Devra, "Has Deregulation Decreased the Risk of NYSE Seat Ownership?" Economic Letters (1986), pp. 283-289.

Goldman, Samuel P., A Handbook of Stock Exchange Laws, Affecting members, their customers, brokers and investors (New York: Doubleday, Page and Company, 1914).

Jarrell, Gregg A., "Change at the Exchange: The Causes and Effects of Deregulation,” Journal of Law and Economics Vol. 27, No. 2 (October 1984), pp. 273-307.

Jones, Charles M., “A Century of Stock Market Liquidity and Trading Costs,” (Graduate School of Business, Columbia University, 2002).

Keim, Donald B. and Anath Madhavan, "The Information Contained in Stock Exchange Seat Prices,” New York Stock Exchange Working Paper, (February 1997).

Keim, Donald B and Anath Madhavan, "The Relation between Stock Market Movements and NYSE Seat Prices,” Journal of Finance LV, 8 (December 2000), pp. 2817-2840. 
Laux, Paul "Trade Sizes and Theories of the Bid-Ask Spread,” Journal of Financial Research Vol. XVI, No. 3 (Fall 1983), pp. 237-249.

Madhavan, Anath, "Market microstructure: A survey,” Journal of Financial Markets 3 (2000), pp. 205-258.

Meeker, J. Edward, The Work of the Stock Exchange (New York: The Ronald Press Company, 1922).

Menyah, Kojo, and Krishna Paudyal, "The Determinants and Dynamics of Bid-Ask Spreads on the London Stock Exchange,” Journal of Financial Research Vol. XIX, No. 3 (Fall 1996), pp. 377-394.

New York Curb Exchange, New York Curb Exchange---History, Organization (New York: New York Curb Exchange, 1929)

New York Stock Exchange. Archives.

New York Stock Exchange. Committee on Admissions.

New York Stock Exchange. Minutes of the Governing Committee.

New York Stock Exchange, Report of the President, various years.

New York Stock Exchange, Yearbook., various years.

New York Stock Exchange. www.nyse.com. historicalseatprice.html.

New York Herald.

New York Times

Poon Ser-Huang and Clive W. Granger, "Forecasting Volatility in Financial Markets," Journal of Economic Literature, 41, 2 (June 2003), pp. 426-477.

Schwert, G. William, "Public Regulation of National Securities Exchanges: A Test of the Capture Hypothesis,” (Spring 1977) Vol. 8 No. 1, pp. 128-150.

Schwert G. William, "Stock Exchange Seats as Capital Assets," Journal of Financial Economics4(1977), pp. 51-78.

Stoll, Hans R. "The Supply of Dealer Services in Securities Markets, Journal of Finance 33 (1978), pp. 1133-1151.

Stoll, Hans R., “Friction,” Journal of Finance 55, 4 (August 2000), pp. 1479-1514.

The World. 